\title{
Geostatistical Modeling of Pore Velocity
}

June 1981

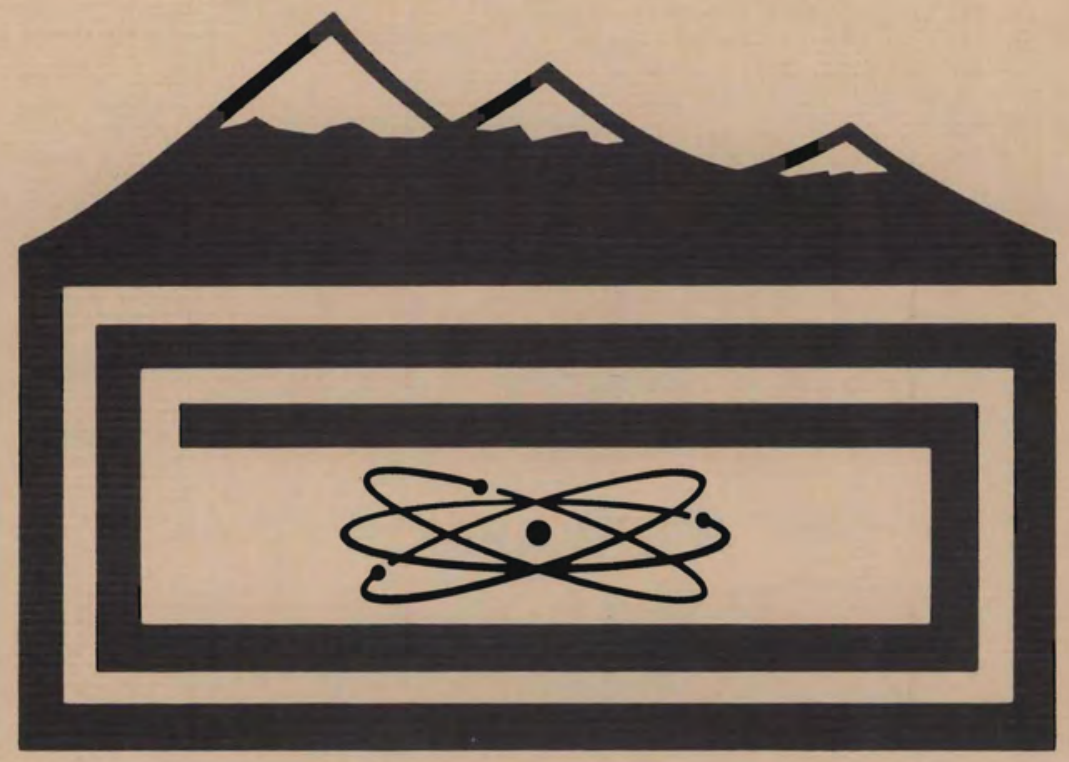

Prepared for the Office of Nuclear Waste Isolation, U.S. Department of Energy under Contract DE-AC06-76RLO 1830

Pacific Northwest Laboratory Operated for the U.S. Department of Energy by Battelle Memorial Institute

\section{* Battelle}




\title{
NOTICE
}

This report was prepared as an account of work sponsored by the United States Government. Neither the United States nor the Department of Energy, nor any of their employees, nor any of their contractors, subcontractors, or their employees, makes any warranty, express or implied, or assumes any legal liability or responsibility for the accuracy, completeness or usefulness of any information, apparatus, product or process disclosed, or represents that its use would not infringe privately owned rights.

The views, opinions and conclusions contained in this report are those of the contractor and do not necessarily represent those of the United States Government or the United States Department of Energy.

\author{
PACIFIC NORTHWEST LABORATORY \\ operated by \\ BATTELLE \\ for the \\ UNITED STATES DEPARTMENT OF ENERGY \\ Under Contract DE-AC06-76RLO 1830
}

\author{
Printed in the United States of America \\ Available from \\ National Technical Information Service \\ United States Department of Commerce \\ 5285 Port Royal Road \\ Springfield, Virginia 22151
}

Price: Printed Copy $\$$ $*$ Microfiche $\$ 3.00$

$\begin{array}{cr}\text { •Pages } & \begin{array}{c}\text { NTIS } \\ \text { Selling Pric }\end{array} \\ 001-025 & \$ 4.00 \\ 026-050 & \$ 4.50 \\ 051-075 & \$ 5.25 \\ 076-100 & \$ 6.00 \\ 101-125 & \$ 6.50 \\ 126-150 & \$ 7.25 \\ 151-175 & \$ 8.00 \\ 176-200 & \$ 9.00 \\ 201-225 & \$ 9.25 \\ 226-250 & \$ 9.50 \\ 251-275 & \$ 10.75 \\ 276-300 & \$ 11.00\end{array}$


Assessment of Effectiveness of Geologic Isolation Systems

GEOSTATISTICAL MODELING OF PORE VELOCITY
J. L. Devary
P. G. Doctor

June 1981

Work Supported by the Office of Nuclear Waste Isolation under Contract DE-AC06-76RLO 1830 with the U.S. Department of Energy

Pacific Northwest Laboratory

Richland, Washington 99352 


\section{ACKNOWLEDGMENT}

This research, supported by the Assessment of Effectiveness of Geologic Isolation Systems (AEGIS) Program, was conducted by the Pacific Northwest Laboratory. The program is sponsored by the Office of Nuclear Waste Isolation managed by Battelle Memorial Institute for the Department of Energy under Contract DE-ACO6-76RLO 1830. 


\section{SUMMARY}

A significant part of evaluating a geologic formation as a nuclear waste repository involves the modeling of contaminant transport in the surrounding media in the event the repository is breached. The commonly used contaminant transport models are deterministic. However, the spatial variability of hydrologic field parameters introduces uncertainties into contaminant transport predictions. This paper discusses the application of geostatistical techniques to the modeling of spatially varying hydrologic field parameters required as input to contaminant transport analyses.

Kriging estimation techniques were applied to Hanford Reservation field data to calculate hydraulic conductivity and the ground-water potential gradients. These quantitites were statistically combined to estimate the groundwater pore velocity and to characterize the pore velocity estimation error.

Combining geostatistical modeling techniques with product error propagation techniques results in an effective stochastic characterization of groundwater pore velocity, a hydrologic parameter required for contaminant transport analyses. 
• 


\section{CONTENTS}

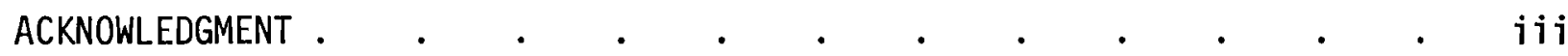
SUMMARY

1.0 INTRODUCTION

2.0 DESCRIPTION OF HANFORD FIELD DATA . . . . . . . . . . . 3

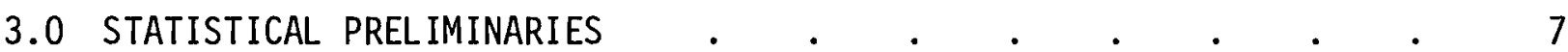

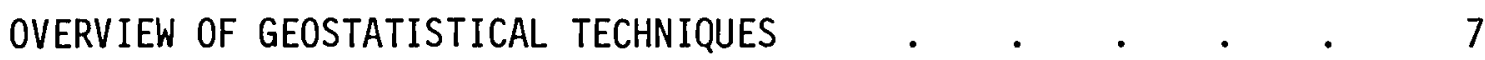

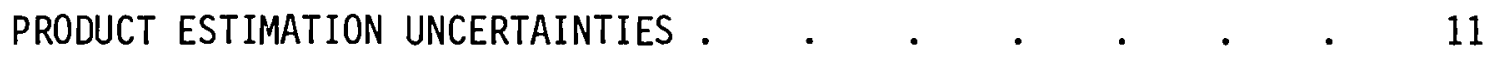

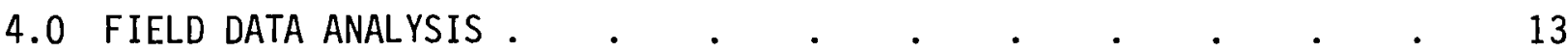

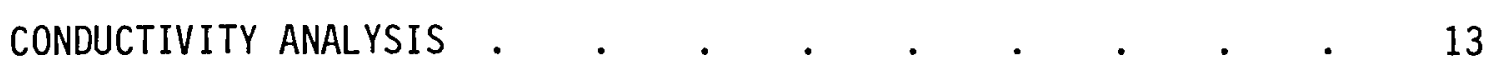

POTENTIAL GRADIENT ANALYSIS . . . . . . . . . . . 18

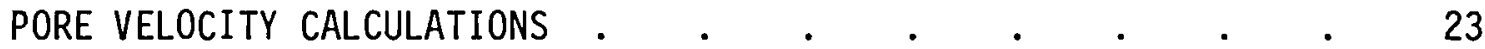

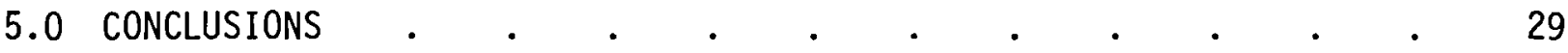

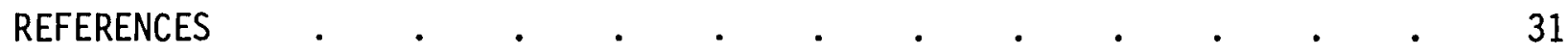




\section{LIST OF FIGURES}

2.1 Location of the Pasco Basin Within the Columbia River Plateau

2.2 Location of the Hydrologic Field of Study . . . . . 5

4.1 Hydraulic Conductivity Data Values . . . . . . . 14

4.2 Covariance Regression for $\log k(x)$ Data . . . . . 15

4.3 Contour Plot of $\log k^{*}(x)$. . . . . . . . . 16

4.4 Kriging Error Standard Deviation Plot for $\log k^{\star}(x)$. . . 17

4.5 Potential Data Values . . . . . . . . . . 19

4.6 Covariance Regression for $\Phi(x)$ Data . . . . . . 20

4.7 Contour Plot of $\Phi^{\star}(\mathrm{x})$. . . . . . . . . . 21

4.8 Contour Plot of $\Phi^{*}{ }_{1}$, (east direction gradient) . . . . 22

4.9 Contour Plot of $\Phi^{\star}{ }^{2}(x)$, (north direction gradient) . . . 23

4.10 Kriging Error Standard Deviation Plot for $\Phi^{\star}{ }_{1}(x)$. . . 24

4.11 Contour Plot of $v_{1}{ }^{*}(x)$ (east direction) $x^{1} \cdot . \quad . \quad . \quad 25$

4.12 Contour Plot of $v_{2}^{\star}(x)$ (north direction) . . . . . 26

$4.13 \begin{aligned} & \text { Contour Plot of the Estimation Error Standard Deviation for : } \\ & v_{1}{ }^{*}(\mathrm{x}) \text {. . . . . }\end{aligned}$

4.14 Contour Plot of the Estimation Error Standard
Deviation for $v_{2}^{*}(x) . . . .$. 


\subsection{INTRODUCTION}

Hydrologic modeling enters into the evaluation of a geologic formation as a potential site for a nuclear waste repository. The modeling provides a means for predicting the concentrations and transit times of contaminants in the ground water should the repository be breached. Hydrologic modeling can be an ambitious undertaking, depending on the complexity of the system to be modeled, because it involves the numeric solution of partial differential equations. The fact that hydrologic data are subject to spatial variability as well as measurement error has made hydrologists realize that the models are also stochastic (Bakr et a1. 1978; Delhomme 1978, 1979; Gambolati and Giampiero 1979; Gelhar, Gutjahr and Naff 1979; Giampiero and Gambolate 1979; Gutjahr et a). 1978). This paper discusses the application of geostatistical techniques to the stochastical modeling of spatially varying hydrologic field parameters.

The basis of the traditional transport modeling is to provide a conservation of mass statement with convection to yield the expression:

$$
\frac{\partial}{\partial t} c(x, t)+\nabla \cdot v(x) c(x, t)=s
$$

where $c(x, t)$ represents the contaminant concentration at time $t$ for spatial location $x=\left(x^{1}, x^{2}\right)$ in the plane, $v(x)=\left(v_{1}(x), v_{2}(x)\right)$ is the ground-water pore velocity vector at location $x$ and is assumed to be time invariant, and $s$ is a source term. The deterministic approach assumes that the velocities are known perfectly at every location $x$. This is not true. The $v(x)$ are random quantities that must be estimated from discrete measurements of various combinations of the following data: hydraulic conductivity, effective porosity, and ground-water potential (level). Thus, the pore velocity may be considered as the realization of a stochastic process whose index set is contained in the plane. Equation (1.1) may be considered as a partial differential equation with stochastic coefficients. To solve for $c(x, t)$ (also a stochastic quantity) it is necessary to have an estimate of $v(x)$, denoted $v^{*}(x)$, as well as a characterization of the estimation error, $v(x)-v^{*}(x)$. Specifically, the solution 
of (1.1) requires at least $v^{\star}(x)$, the bias of $v^{\star}(x)$, and the covariance structure of $v(x)-v^{*}(x)$.

The pore velocity is related to the hydraulic conductivity $(k)$, effective porosity $(p)$, and ground-water potential $(\Phi)$ through Darcy's law:

$$
v(x)=\left(v_{1}(x), v_{2}(x)\right)=-(k(x) / p(x)) \nabla \Phi(x)
$$

We shall use geostatistical techniques, e.g., kriging, to estimate conductivity, porosity, and potential gradient surfaces from hydrologic field data. We shall then statistically combine these quantities to produce unbiased estimates of $v(x)$ and to stochastically characterize the estimation error, $v(x)-v^{*}(x)$. These techniques will be demonstrated using hydrologic field data from the Hanford Reservation.

The remainder of this paper consists of four sections that describe 1) the Hanford Reservation field data, 2) the statistical methods used to analyze hydrologic field data, 3 ) the stochastic modeling of pore velocity from the Hanford data, and 4) conclusions. 


\subsection{DESCRIPTION OF HANFORD FIELD DATA}

The Hanford nuclear reservation is located within the Pasco Basin, in the northcentral portion of the physiographic province known as the Columbia River Plateau (see Figure 2.1 (Lillie and Richard 1977)). Some 2200 wells drilled in various locations within the reservation boundaries are collectively known as the Hanford wells. They were not all drilled for the same purpose. Approximately 200 are old farm wells and largely abandoned. The newer wells were either drilled by the U.S. Department of Energy (DOE) prime contractors or the U.S. Geological Survey. The majority of the 1700 functioning wells are used for ground-water hydrological data collection or basalt stratigraphic characterization. The wells are currently the responsibility of Rockwell Hanford Operations.

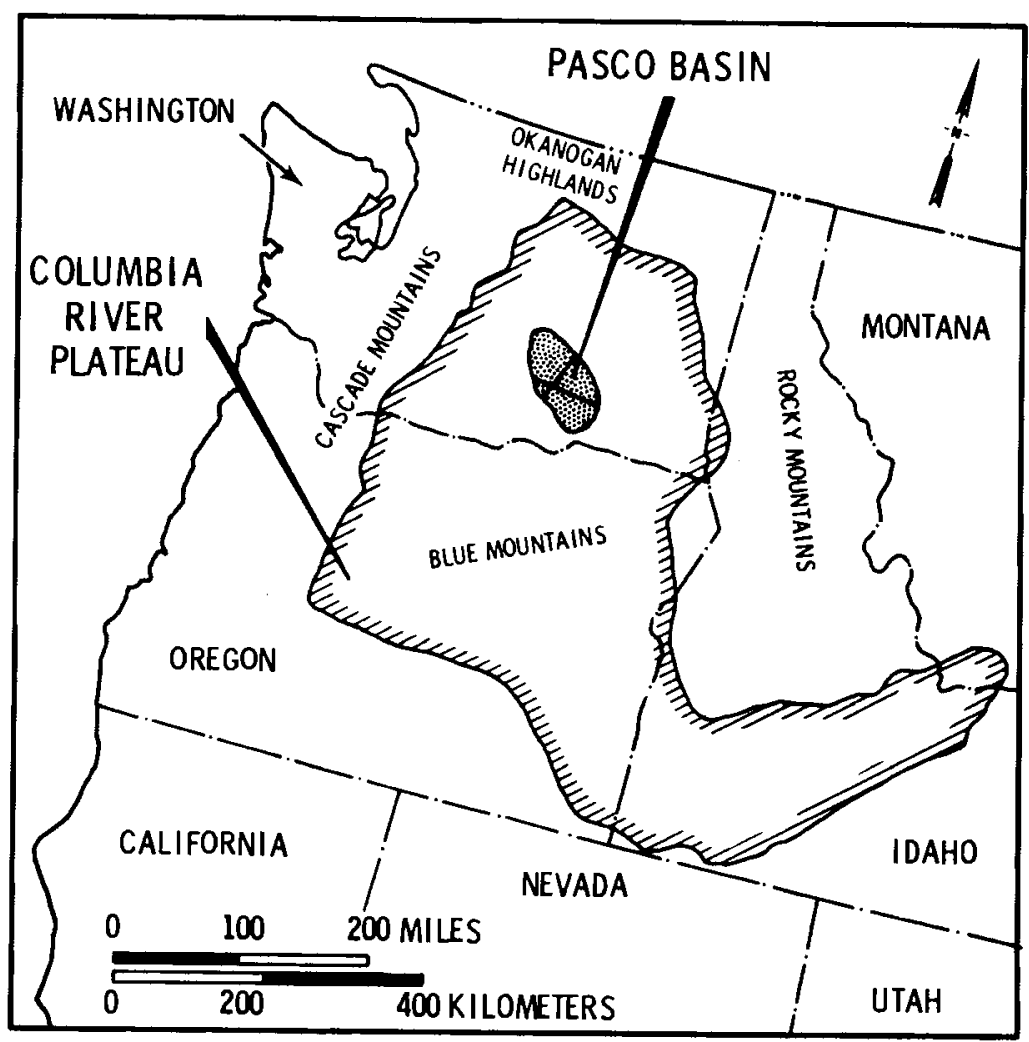

FIGURE 2.1. Location of the Pasco Basin Within the Columbia River Plateau 


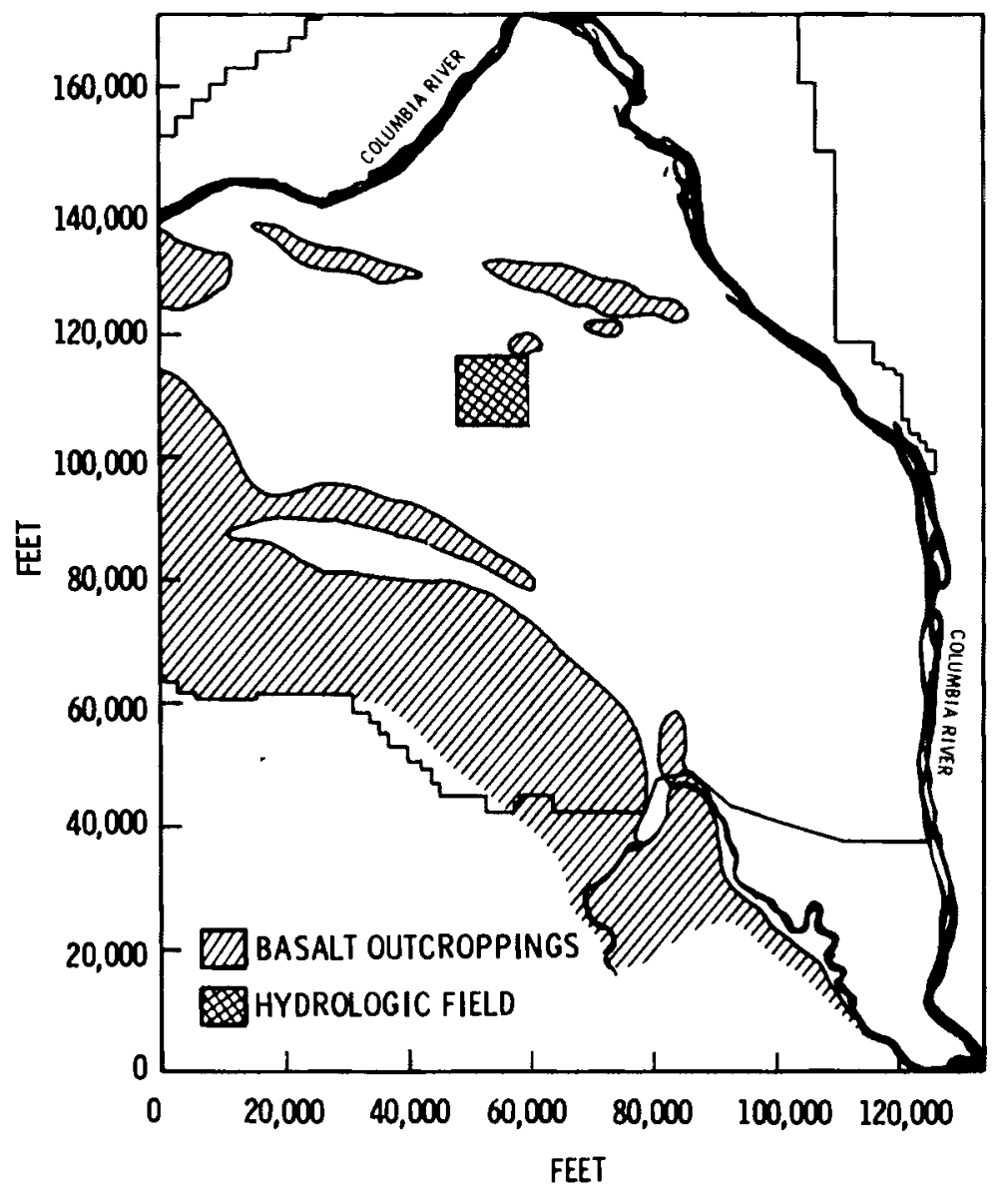

FIGURE 2.2. Location of Hydrologic Field of Study 
About 850 wells are drilled into the ground-water table. From them, periodic measurements of ground-water potential and hydraulic conductivity (among others) are taken. The Water and Land Resources Department of the Pacific Northwest Laboratory (PNL) maintains data from the wells in what is called the Hanford Wells Data Base. The well locations are referenced with respect to a rectangular grid system (measured in feet) whose origin is at the southwest boundary of the Hanford Site. The area covered by the grid is approximately $144,000 \mathrm{ft}(27 \mathrm{mi})$ by $172,000 \mathrm{ft}(32 \mathrm{mi})$.

For this study we selected a $20,000-\mathrm{ft} \times 20,000-\mathrm{ft}$ region within the Hanford reservation known to have a tremendous range of hydraulic conductivity values (see Figure 2.2). We felt this type of hydrologic data set was needed to truly determine the applicability of geostatistical techniques to groundwater pore velocity modeling. Hydraulic conductivity and ground-water potential measurements were made at the $2000-\mathrm{ft} \times 2000-\mathrm{ft}$ square grid points of the region. Unfortunately effective porosity values were not known at these grid points and a constant porosity value of 0.10 had to be used throughout the region; this value was supplied by PNL hydrologists. A listing of the conductivity and potential data values may be found in Section 4.0 of this report. 


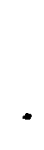




\subsection{STATISTICAL PRELIMINARIES}

OVERVIEW OF GEOSTATISTICAL TECHNIQUES

Geostatistics and kriging are statistical techniques that can be used to estimate a surface from spatially distributed data. They were developed in the early 1960 's, primarily by the French mathematician Georges Matheron, to solve mining estimation problems (Agterberg 1974; Akima 1975; Chiles 1975; Davis 1973; Delfiner and Delhomme 1975; Krige 1966; Matheron 1963; 1971; 01ea 1974). Geostatistics is the more general term, but kriging, which refers to the estimation method itself, is often used in a more general sense.

Let $Z(x)$ be the value of a continuous surface at location $x=\left(x^{1}, x^{2}\right)$ in the plane. $Z(x)$ is assumed to be the realization of a stochastic process. Given that $Z$ is observed at discrete locations $x_{1}, \ldots, x_{n}$, the kriging estimate of a random variable $W$ is the linear combination of the observed data

$$
w^{*}=\sum_{i} \lambda_{i} Z\left(x_{i}\right)
$$

such that:

$$
\begin{aligned}
& E\left(W-W^{*}\right)=0 \\
& E\left(W-W^{*}\right)^{2} \text { is minimal }
\end{aligned}
$$

(E denotes the probabilistic expectation operator.) Typically $W$ is one of the following random variables:

(i) $Z\left(x_{0}\right)-$ punctual value

(ii) $\quad \nabla Z\left(x_{0}\right)=\left(Z_{x}{ }_{1}\left(x_{0}\right), Z_{x^{2}}\left(x_{0}\right)\right)$ - gradient value

(iii) $\int_{A} Z(x) d x$ - integrated value over a set $A$ in the plane

(iv) $\quad \nabla^{2} z\left(x_{0}\right)=z_{x}{ }^{1}{ }^{1}{ }\left(x_{0}\right)+z_{x^{2}{ }^{2}}\left(x_{0}\right)-$ Laplacian value

We shall be concerned only with kriging punctual or gradient values for $Z$ surfaces. 
Traditional least squares regression analysis is not appropriate for estimating $W$ because the observed $Z$ data is not necessarily statistically independent. Least squares regression estimates ignore any stochastic continuity (or correlation) present in the $Z$ surface.

Assume that $Z(x)$ is the realization of a stochastic process that locally has a polynomial first moment and finite second moment. Specifically, for any point $x_{0}$ in the plane there exists a neighborhood $N$ of $x_{0}$ such that for $x$ and $y$ within $\mathrm{N}$ :

$$
\begin{aligned}
& E[Z(x)]=m(x)=\sum_{\ell} a_{\ell} f^{\ell}(x) \text { where }\left\{a_{\ell}\right\} \text { are unknown constants and } \\
& \left\{f^{\ell}(x)\right\} \text { are monomial functions of some finite order }
\end{aligned}
$$

$$
E[Z(x)-m(x)][Z(y)-m(y)]=c(x, y) \text { is a known covariance function. }
$$

The monomial functions of order one are for $x=\left(x^{1}, x^{2}\right), 1, x^{1}, x^{2}$. The monomial functions of orders two are $1, x^{1}, x^{2},\left(x^{1}\right)^{2}, x^{1} x^{2},\left(x^{2}\right)^{2}$.

The kriging estimate of a random variable involves calculating the optimal set of kriging weights $\lambda_{1}, \ldots, \lambda_{n}$ such that

$$
E\left[W-W^{\star}\right]^{2}=\operatorname{Var}(W)+\sum_{i} \sum_{j} \lambda_{i} \lambda_{j} c\left(x_{i}, x_{j}\right)-2 \sum_{i} \lambda_{i} \operatorname{Cov}\left(W, Z\left(x_{i}\right)\right)
$$

is minimized subject to the constraint $E\left[W-W^{*}\right]=0$. (Var and Cov respectively denote the variance and covariance operators.) The determination of the kriging weights depends only upon the covariance and mean structure of $W$ and $Z$. The kriging weights do not depend upon the observed $Z$ data.

For punctual kriging, $W=Z\left(x_{0}\right)$, the quantity

$$
\begin{gathered}
E\left[Z\left(x_{0}\right)-Z^{\star}\left(x_{0}\right)\right]^{2}= \\
\operatorname{Var}\left(Z\left(x_{0}\right)\right)+\sum_{i} \sum_{j} \lambda_{i} \lambda_{j} c\left(x_{j}, x_{j}\right)-2 \sum_{i} \lambda_{i} c\left(x_{0}, x_{j}\right)
\end{gathered}
$$


is minimized subject to the constraints

$$
\sum_{i} \lambda_{i} f^{\ell}\left(x_{i}\right)=f^{\ell}\left(x_{0}\right), \text { a } 11 \ell
$$

The covariance of the kriging error is given by

$$
\begin{gathered}
\operatorname{Cov}\left(z\left(x_{0}\right)-z^{\star}\left(x_{0}\right), z\left(y_{0}\right)-z^{\star}\left(y_{0}\right)\right)=c\left(x_{0}, y_{0}\right) \\
+\sum_{i} \sum_{j} \lambda_{j}\left(x_{0}\right) \lambda_{j}\left(y_{0}\right) c\left(x_{i}, x_{j}\right)-\sum_{i} \lambda_{j}\left(x_{0}\right) c\left(x_{i}, y_{0}\right)-\sum_{j} \lambda_{j}\left(y_{0}\right) c\left(x_{j}, x_{0}\right)
\end{gathered}
$$

where $x_{0}, y_{0}, x_{1}, \ldots, x_{n}, \ldots$ are all within the neighborhood $N$.

For gradient kriging, $W=Z_{x}\left(x_{0}\right) k=1$ or 2 , the quantity

$$
\begin{gathered}
E\left[z^{k}\left(x_{0}\right)-Z^{\star} x^{k}\left(x_{0}\right)\right]^{2}=\operatorname{Var}\left(Z_{x^{k}}\left(x_{0}\right)\right)+\sum_{i} \sum_{j} \lambda_{i} \lambda_{j} c\left(x_{i}, x_{j}\right) \\
-2 \sum_{i} \lambda_{i} \operatorname{Cov}\left(Z x^{k}\left(x_{0}\right), Z\left(x_{i}\right)\right)
\end{gathered}
$$

is minimized subject to the constraints

$$
\sum_{i} \lambda_{i} f^{\ell}\left(x_{i}\right)=f_{x^{k}}^{\ell}\left(x_{0}\right), \text { all } \ell
$$

The covariance of the kriging error is given by

$$
\begin{gathered}
\operatorname{Cov}\left(z_{x^{k}}\left(x_{0}\right)-z_{x^{k}}\left(x_{0}\right), z_{x^{k}}\left(y_{0}\right)-z_{x^{k}}\left(y_{0}\right)\right)=\operatorname{Cov}\left(z_{x}{ }^{k}\left(x_{0}\right), z_{x^{k}}\left(y_{0}\right)\right) \\
+\sum_{i} \sum_{j} \lambda_{i}\left(x_{0}\right) \lambda_{j}\left(y_{0}\right) c\left(x_{i}, x_{j}\right)-\sum_{i} \lambda_{j}\left(x_{0}\right) \operatorname{Cov}\left(z_{x^{k}}\left(y_{0}\right), z\left(x_{j}\right)\right) \\
-\sum_{j} \lambda_{j}\left(y_{0}\right) \operatorname{Cov}\left(z_{x^{k}}\left(x_{0}\right), z\left(x_{j}\right)\right)
\end{gathered}
$$


where $x_{0}, y_{0}, x_{1}, \ldots, x_{n}, \ldots$ are all within the neighborhood $N$.

For gradient kriging the underlying stochastic process (for which $Z(x)$ is a realization) is assumed to be differentiable in each of its coordinates with probability equal to one. We shall further assume that the covariance function $c(x, y)=c\left(x^{1}, x^{2}, y^{1}, y^{2}\right)$ has continuous second order partial derivatives in all four coordinates which ensures (Parzen 1962, p. 83) that:

$$
\begin{aligned}
& \operatorname{Cov}\left(z_{x}\left(x_{0}\right), z\left(y_{0}\right)\right)=c_{x}\left(x_{0}, y_{0}\right) \\
& \operatorname{Cov}\left(z_{x}{ }^{k}\left(x_{0}\right), z z_{x}\left(y_{0}\right)\right)=c_{x} k_{y} k^{\left(x_{0}, y_{0}\right)}
\end{aligned}
$$

Furthermore, if $c(x, y)$ is stationary, i.e. $c(x, y)=g\left(x^{1}-y^{1}, x^{2}-y^{2}\right)=g\left(h^{1}, h^{2}\right)$ then

$$
\begin{aligned}
& \operatorname{Cov}\left(z_{x_{k}}\left(x_{0}\right), z\left(y_{0}\right)\right)=g_{h^{k}}\left(x^{1}-y^{1}, x^{2}-y^{2}\right) \\
& \operatorname{Cov}\left(z_{x_{k}}\left(x_{0}\right), z_{x_{k}}\left(y_{0}\right)\right)=-g_{h^{k} k^{k}}\left(x^{1}-y^{1}, x^{2}-y^{2}\right)
\end{aligned}
$$

In order to calculate $W^{*}$ (punctual or gradient) we must know the order of the monomials used in Equations (3.2) and (3.5) and the covariance function $c(x, y)$. In practice, these parameters are never known at the outset and must be estimated from the available $Z$ data. Parameter estimation procedures are described in the data analysis sections of the report.

A computer code was developed by PNL on the UNIVAC 1100/44 at the Richland, Washington DOE computing facility to compute kriging estimates and kriging error covariance quantities, e.g., from Equations (3.3) or (3.6), for stochastic surfaces. The code accepts a user-defined covariance function and regularly spaced input data in a rectangular grid. Its kriging estimates agree with those of BLUEPACK (Delfiner et al. 1979), a much more sophisticated kriging code developed by the Paris School of Mines, Center for Geostatistics. Unfortunately, BLUEPACK does not calculate the kriging error covariance quantities required for the analysis. 
The estimation of pore velocity involves the estimation of the hydrologic parameter surfaces

$$
\begin{aligned}
& k(x) \text { - hydraulic conductivity } \\
& p(x) \text { - effective porosity } \\
& \nabla \Phi(x) \text { - gradient of ground-water potential }
\end{aligned}
$$

which are related by Darcy's Law

$$
v(x)=\left(v_{1}(x), v_{2}(x)\right)=-(k(x) / p(x)) \nabla \Phi(x)
$$

Assuming that $k(x),(1 / p(x))$, and $\nabla \Phi(x)$ are realizations of stochastic processes and unbiased estimators $k^{*}(x),(1 / p(x)) *$, and $\nabla^{*} \Phi$ exist for these hydrologic parameters (e.g. from kriging), then we must consider the estimator

$$
v^{\star}(x)=-k^{\star}(x)(1 / p(x)) * \nabla \star \Phi(x)
$$

Specifically, we must examine the bias and the estimation error of $v^{\star}(x)$.

The unavailability of porosity data determined that $(1 / p(x))$ was modeled as a constant (non-stochastic) value. Furthermore, the spatial correlation between the $K$ and $\Phi$ surface values was entirely attributed to the spatial correlation between the mean values $E[K(x)]$ and $E[\Phi(x)]$. This implies that $K(x)$ and $\Phi(x)$ may be modeled as independent stochastic processes. The estimation bias,

$$
E[v *(x)-v(x)]=0
$$

since $k^{*}(x), \Delta^{*} \Phi(x)$, and $(1 / p(x)) *$ are unbiased, mutually independent estimators of $k(x), \nabla \Phi(x)$, and $(1 / p(x))$. The estimation error variance is given by

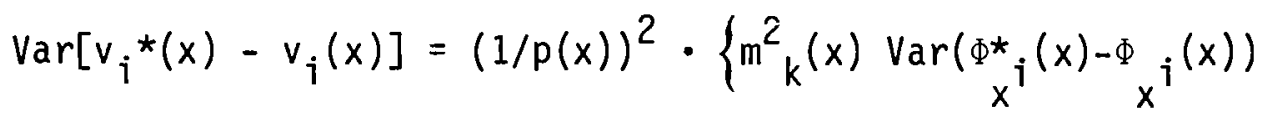

$$
\begin{aligned}
& +m_{\Phi_{x}}^{2}(x) \operatorname{Var}\left(k^{*}(x)-k(x)\right)+\operatorname{Var}\left(\Phi_{x}{ }^{i}(x)\right) \operatorname{Var}(k(x)) \\
& \left.+\operatorname{Var}\left(\Phi_{x_{i}}^{*}(x)\right) \operatorname{Var}\left(k^{\star}(x)\right)-2 \operatorname{Cov}\left(\Phi_{x^{*}}(x), \Phi_{x^{j}}(x)\right) \operatorname{Cov}\left(k^{\star}(x), k(x)\right)\right\}
\end{aligned}
$$


where $i=1$ or 2 and $\nabla \Phi(x)=\left(\Phi_{x}{ }_{1}(x), \Phi_{x^{2}}(x)\right)$. The estimation error cross covariance is given by

$$
\begin{aligned}
& E\left[v^{*}{ }_{j}(x)-v_{j}(x)\right]\left[v^{*}{ }_{j}(y)-v_{j}(y)\right] \\
& =\frac{1}{p(x) p(y)}\left\{m_{k}(x) m_{k}(y) \operatorname{Cov}\left(\Phi_{x}^{*}{ }_{j}(x)-\Phi_{x^{j}}(x), \Phi_{x^{*}}{ }_{j}(y)-\Phi_{x^{j}}(y)\right)\right. \\
& +m_{x^{i}}(x) m_{x^{j}}(y) \operatorname{Cov}\left(k^{*}(x)-k(x), k^{*}(y)-k(y)\right) \\
& +\operatorname{Cov}(k(x), k(y)) \operatorname{Cov}\left(\Phi_{x^{j}}(x), \Phi_{x^{j}}(y)\right) \\
& +\operatorname{Cov}\left(k^{\star}(x),\left(k^{\star}(y)\right) \operatorname{Cov}\left(\Phi^{\star}{ }_{x}{ }^{q}(x), \Phi^{*}{ }^{j}(y)\right)\right. \\
& -\operatorname{Cov}\left(k^{\star}(x), k(y)\right) \operatorname{Cov}\left(\Phi_{x^{*}}(x), \Phi_{x^{j}}(y)\right) \\
& \left.-\operatorname{Cov}\left(k(x), k^{\star}(y)\right) \operatorname{Cov}\left(\Phi_{x}{ }^{j}(x), \Phi^{\star}{ }^{j}(x)\right)\right\}
\end{aligned}
$$

where $i=1$ or $2, j=1$ or 2 , and $x$ and $y$ are values in the plane.

If the porosity $(p(x))$ is also stochastic, then more involved versions of Equations (3.7) and (3.8) containing products of the means and covariances of $(1 / p(x)), k(x)$, and $\Phi_{x}{ }^{j}(x)$ may be derived. 


\subsection{FIELD DATA ANALYSIS}

Geostatistical techniques were used to estimate the conductivity, potential gradient, and pore velocity surfaces from field data collected in a $20,000-\mathrm{ft} x$ 20,000-ft sector within the Hanford Reservation (see Section 2.0 for further details regarding this data set). We discuss first the kriging estimation of the conductivity and potential gradient surfaces; we then discuss the propogation of kriging uncertainties through the pore velocity calculations.

\section{CONDUCTIVITY ANALYSIS}

The conductivity data were measured at the 2000-ft $\times 2000-\mathrm{ft}$ square grid points of the 20,000-ft $\times 20,000-\mathrm{ft}$ region of the Hanford Reservation. Figure 4.1 displays these data values. The extreme spatial variability of the conductivity data (range greater than $100,000 \mathrm{ft} /$ day) precluded kriging $k$ estimates directly. Taking natural logarithms permitted the following stochastic model to be made for the conductivity data:

$$
\log k(x)=k^{\prime}(x)=m_{k^{\prime}}(x)+e(x)
$$

where $m_{k^{\prime}}(x)=E\left[k^{\prime}(x)\right]$ is a cubic polynomial function of $x=\left(x^{1}, x^{2}\right)$ in the $p l a n e$ and $e(x)$ is the realization of Gaussian stationary process. This implies $k(x)$ is the realization of a lognormal process.

A least squares linear regression fit estimated the mean function $m_{k^{\prime}}(x)$ and permitted the estimation of $e(x)$ at observed grid points; the estimated value of $e(x)$ is simply the residual value at grid point $x$. The covariance function of $e(x)$,

$$
E[e(x) e(x+h)]=c(x, x+h)=c(h)
$$

was estimated from

$$
\frac{1}{N} \sum r(x) r(x+h)
$$




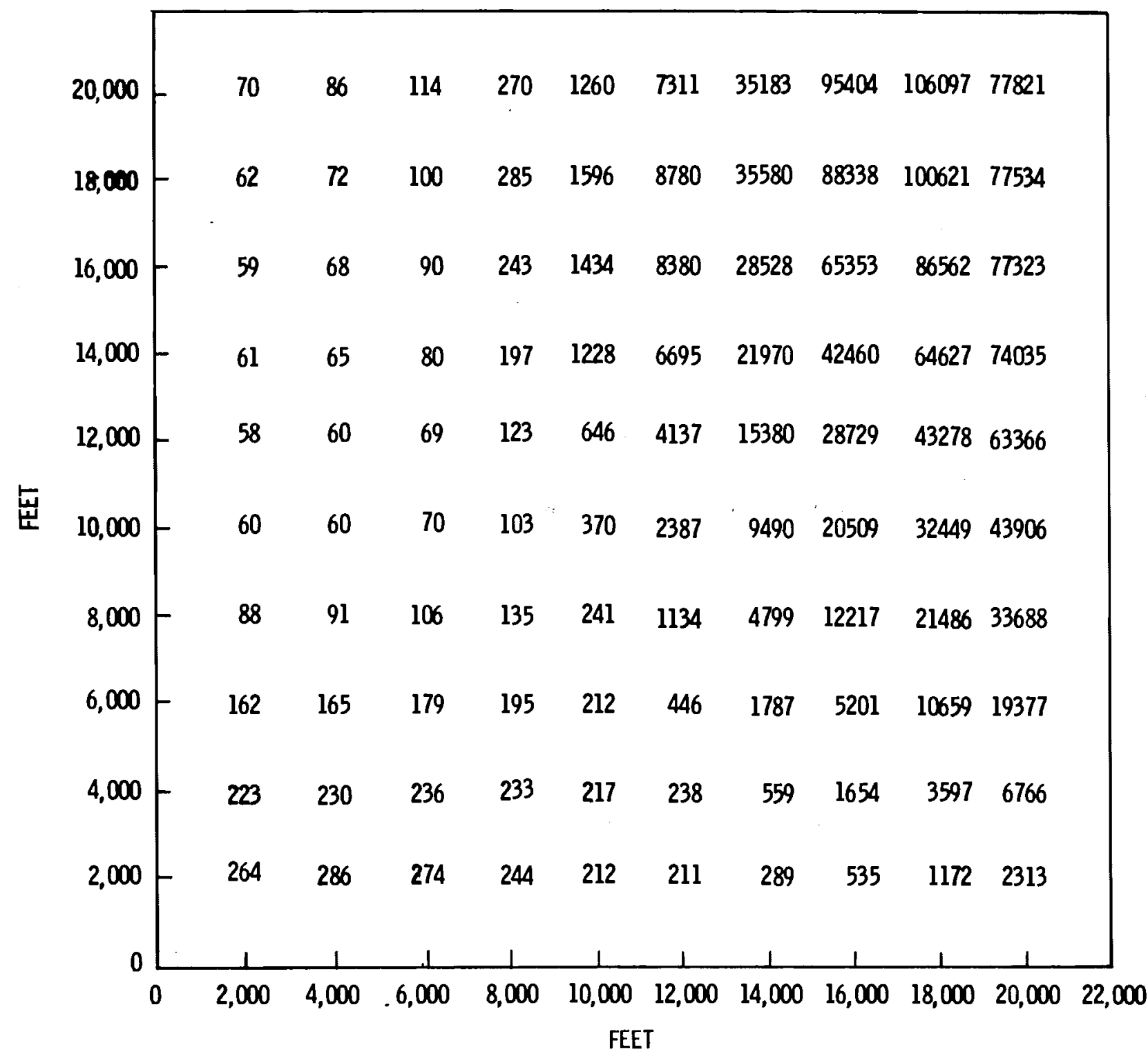

FIGURE 4.1. Hydraulic Conductivity Data Values (ft/day)

where $r(x)$ is the residual value at grid point $x, h=\left(h^{1}, h^{2}\right)$ is a twodimensional increment, and the sum is taken over all grid point pairs (cardinality $=N$ ) whose difference equals $h$. A nonlinear regression fit to the covariance data yielded

$$
c(h)=0.151 \exp \left(-0.565(h / 2000)^{2}\right)
$$

Figure 4.2 displays the regression fit. 


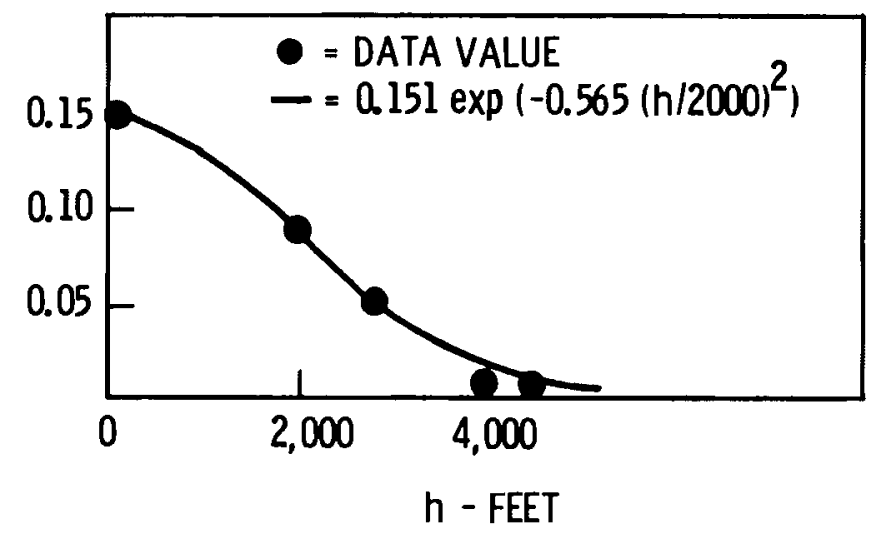

FIGURE 4.2. Covariance Regression for $\log k(x)$ Data

The covariance function of Equation (4.2) was input to the PNL kriging routine to estimate $k^{\prime}(x)$ on the $[4000-\mathrm{ft}, 16,000-\mathrm{ft}] \times[4000-\mathrm{ft}, 16,000-\mathrm{ft}]$ region. Figure 4.3 displays the kriged values of $k^{\prime}(x)$ on this region.

Figure 4.4 displays the kriging error standard deviation for $k^{\prime}(x)$ on the $[4000-\mathrm{ft}, 16,000-\mathrm{ft}] \times[4000-\mathrm{ft}, 16,000-\mathrm{ft}]$ region. The kriging error standard deviation is the square root of the kriging error variance of Equation (3.1). Notice that the kriging error standard deviation is zero at the observed grid points and maximal at the center of each 2000-ft $\times 2000-\mathrm{ft}$ square. This is because kriging is an exact interpolator. The average value of the kriging error variance was 0.00283 .

Examination of the kriging error cross covariance function permitted the following approximation to be made (see Equation (3.3)).

$$
\operatorname{Cov}\left(k^{\prime}(x)-k^{\prime *}(x), k^{\prime}(y)-k^{\prime *}(y)\right)=\frac{0.00283}{1+7.04(d / 2000)^{2}}
$$

where $d$ is the distance between $x$ and $y$. Furthermore, we found that the following two quantities were approximately equal:

$$
\operatorname{Cov}\left(k^{\prime *}(x), k^{\prime}(y)\right)=\operatorname{Cov}\left(k^{\prime *}(x), k^{\prime *}(y)\right)
$$




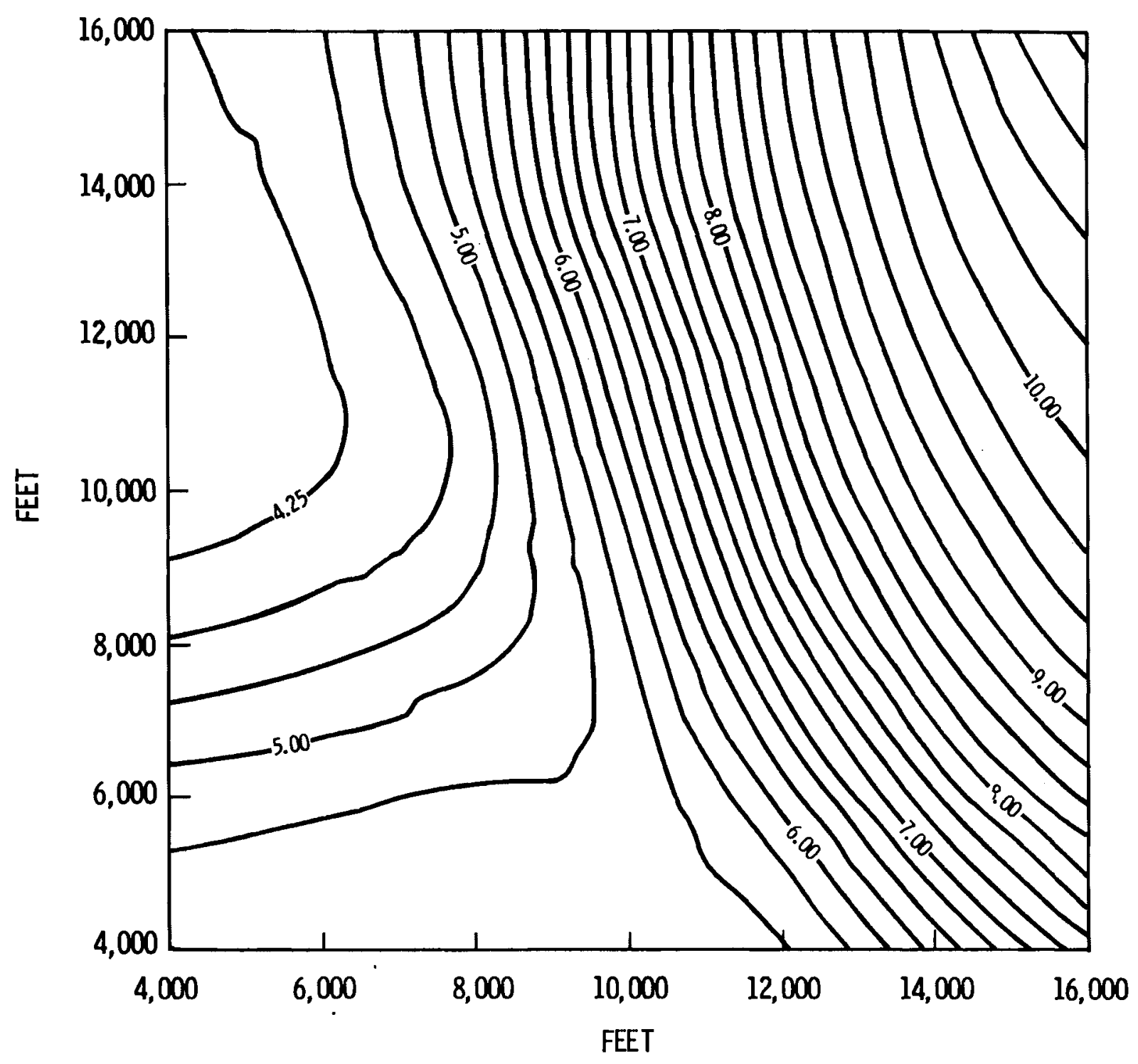

FIGURE 4.3. Contour Plot for $\log k^{\star}(x)$

This is because the kriging estimate, $k^{\prime *}(x)$, is essentially uncorrelated with the kriging error, $k^{\prime}(y)-k^{\prime *}(y)$. This permits the following approximation:

$$
\begin{gathered}
\operatorname{Cov}\left(k^{\prime}(x), k^{\prime}(y)\right)= \\
\operatorname{Cov}\left(k^{\prime *}(x), k^{\prime *}(y)\right)+\operatorname{Cov}\left(k^{\prime}(x)-k^{\prime *}(x), k^{\prime}(y)-k^{\prime *}(y)\right)
\end{gathered}
$$




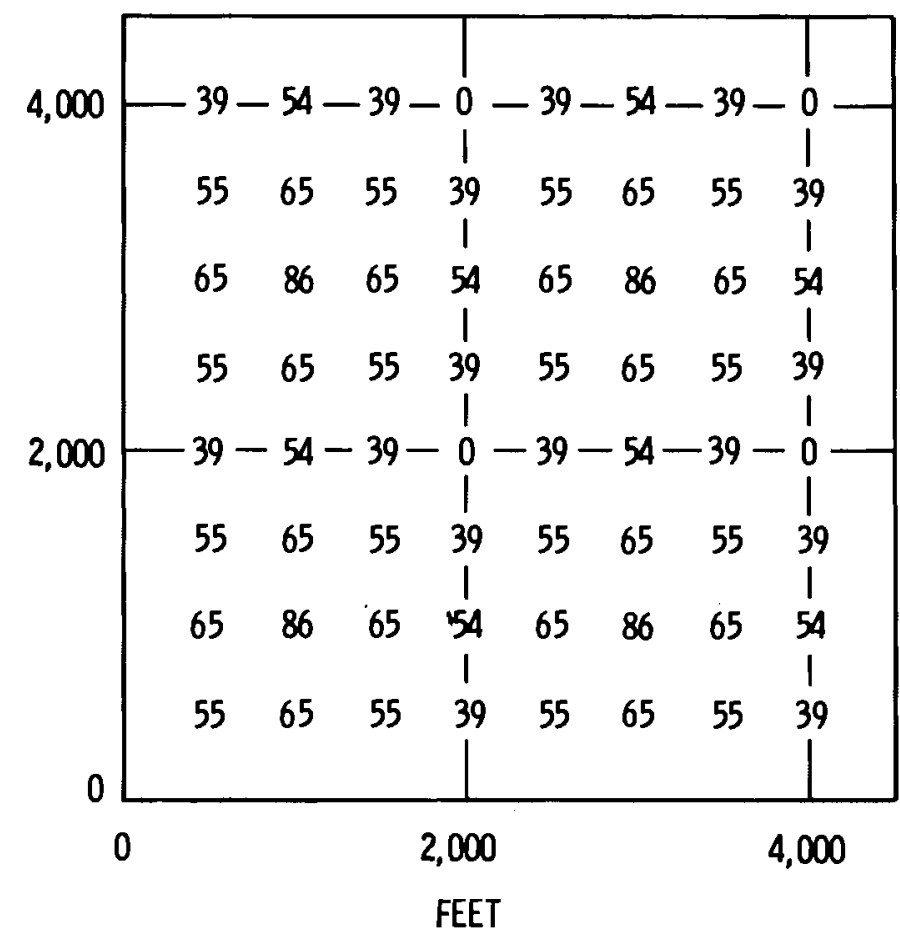

FIGURE 4.4. Kriging Error Standard Deviation Plot for $\log k^{*}(x)$ (Scaling $=x 10^{-3}$ )

which will simplify the product uncertainty calculations described in Section 3.0.

Since $k(x)$ is lognormally distributed

$$
E\left[\exp \left(k^{\prime}(x)\right)\right]=\exp \left(m_{k^{\prime}}(x)+0.5 \operatorname{Var}\left(k^{\prime}(x)\right)\right.
$$

which implies, using Equation (4.5), that

$$
\begin{aligned}
k^{*}(x) & =\exp \left(k^{\prime}(x)\right) x \exp \left(0 . 5 \left(\operatorname{Var}\left(k^{\prime}(x)\right)-\operatorname{Var}\left(k^{\prime *}(x)\right)\right.\right. \\
& =1.005 \exp \left(k^{\prime}(x)\right)
\end{aligned}
$$

is an unbiased estimator of $k(x)$. The variance of $k^{*}(x)$ is given by

$$
\operatorname{Var}\left(k^{*}(x)\right)=\left(k^{\star}(x)^{2}\left(\exp \left(\operatorname{Var}\left(k^{\prime *}(x)\right)\right)-1\right)=0.16\left(k^{\star}(x)\right)^{2}\right.
$$


and the estimation error variance is given by

$$
\begin{aligned}
\operatorname{Var}\left(k(x)-k^{\star}(x)\right) & =\left(k^{\star}(x)\right)^{2}\left(\operatorname { e x p } \left(\operatorname{Var}\left(k^{\prime}(x)\right)-\exp \left(\operatorname{Var}\left(k^{\prime *}(x)\right)\right)\right.\right. \\
& =0.0033\left(k^{\star}(x)\right)^{2}
\end{aligned}
$$

\section{POTENTIAL GRADIENT ANALYSIS}

The potential (ground-water level) data were measured at the same grid positions within the Hanford Reservation as the conductivity data. Figure 4.5 displays these data values. The following stochastic model was used to describe the potential data:

$$
\Phi(x)=m_{\Phi}(x)+e(x)
$$

where $m_{\Phi}(x)=E[\Phi(x)]$ is a quadratic polynomial function of $x=\left(x^{1}, x^{2}\right)$ and $e(x)$ is the realization of a Gaussian stationary process.

A least squares linear regression fit estimated the mean function $m_{\Phi}(x)$ and permitted the estimation of $e(x)$ at the observed grid points. The covariance of $e(x)$ was estimated from the residuals using Equation (4.1) and a nonlinear regression fit as in the previous analysis of the conductivity data. The covariance of $e(x)$ is given by:

$$
c(h)=22.27 \exp \left(-0.45(h / 2000)^{2}\right)
$$

Figure 4.6 displays the regression fit.

The residuals from the $\log$ conductivity data fit (see Equation (4.2)) were cross correlated with the residuals from the potential data fit (see Equation (4.10)). No significant cross correlation was found between the log conductivity and potential residual data sets. This implies that the conductivity and potential gradient surfaces are realizations of independent stochastic processes. This uncorrelated spatial behavior between these sets of 


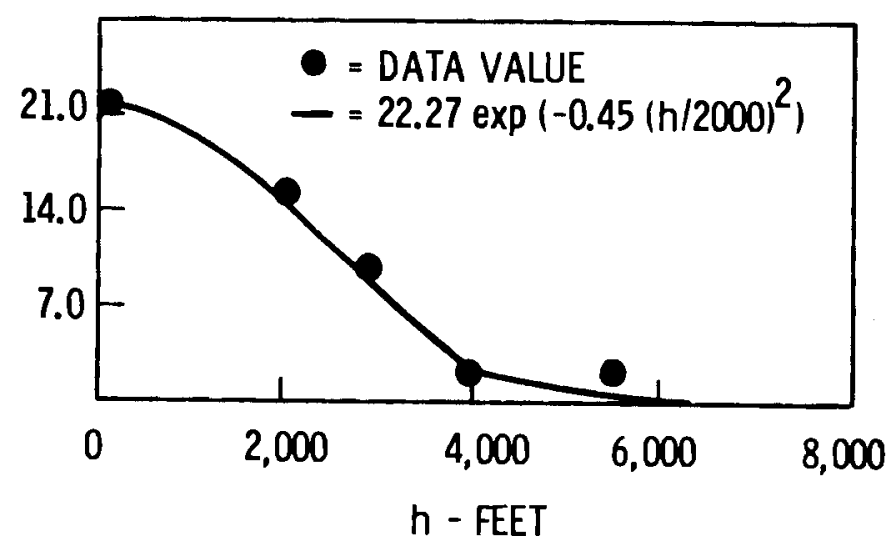

FIGURE 4.6. Covariance Regression for $\phi(x)$ Data

Since the covariance function of Equation (4.10) satisfies the regularity conditions described in Section 3.0 and by definition the potential surface is smooth, we were able to krige estimates of the potential gradient. Figures 4.8 and 4.9 display the kriged values of $\Phi_{x_{1}}(x)$ and $\Phi_{x^{2}}(x)$, respectively, for the $[4000-\mathrm{ft}, 16,000-\mathrm{ft}] \times[4000-\mathrm{ft}, 16,000-\mathrm{ft}]$ region.

Figure 4.10 displays the kriging error standard deviation for $\phi_{x_{1}}(x)$ on the $[4000-\mathrm{ft}, 16,000-\mathrm{ft}] \times[4000-\mathrm{ft}, 16,000-\mathrm{ft}]$ region. Notice that the kriging error standard deviation is minimal midway between two grid points with the same ordinate $\left(x^{2}\right)$ and the kriging error standard deviation is maximal midway between two grid points with the same abscissa $\left(x^{1}\right) \cdot \Phi_{x^{1}}\left(x_{0}\right)$ most accurately estimated when $\Phi$ is most accurately known on the horizontal line

$$
\left\{\left(x^{1}, x^{2}\right): x^{2}=x_{0}^{2}\right\}
$$

The average value of the kriging error variance for $\Phi_{x}{ }_{1}$ or $\phi_{x^{2}}$ was $1.39 \times 10^{-7}$.

Examination of the kriging error cross-covariance function allowed the following approximation to be made:

$$
\operatorname{Cov}\left(\Phi_{i}(x)-\Phi_{x}^{*}{ }_{j}(x), \Phi_{x}{ }_{j}(y)-\Phi^{*}{ }_{i}(y)\right)=\frac{1.39 \times 10^{-7}}{1+7.61(d / 2000)^{2}}
$$




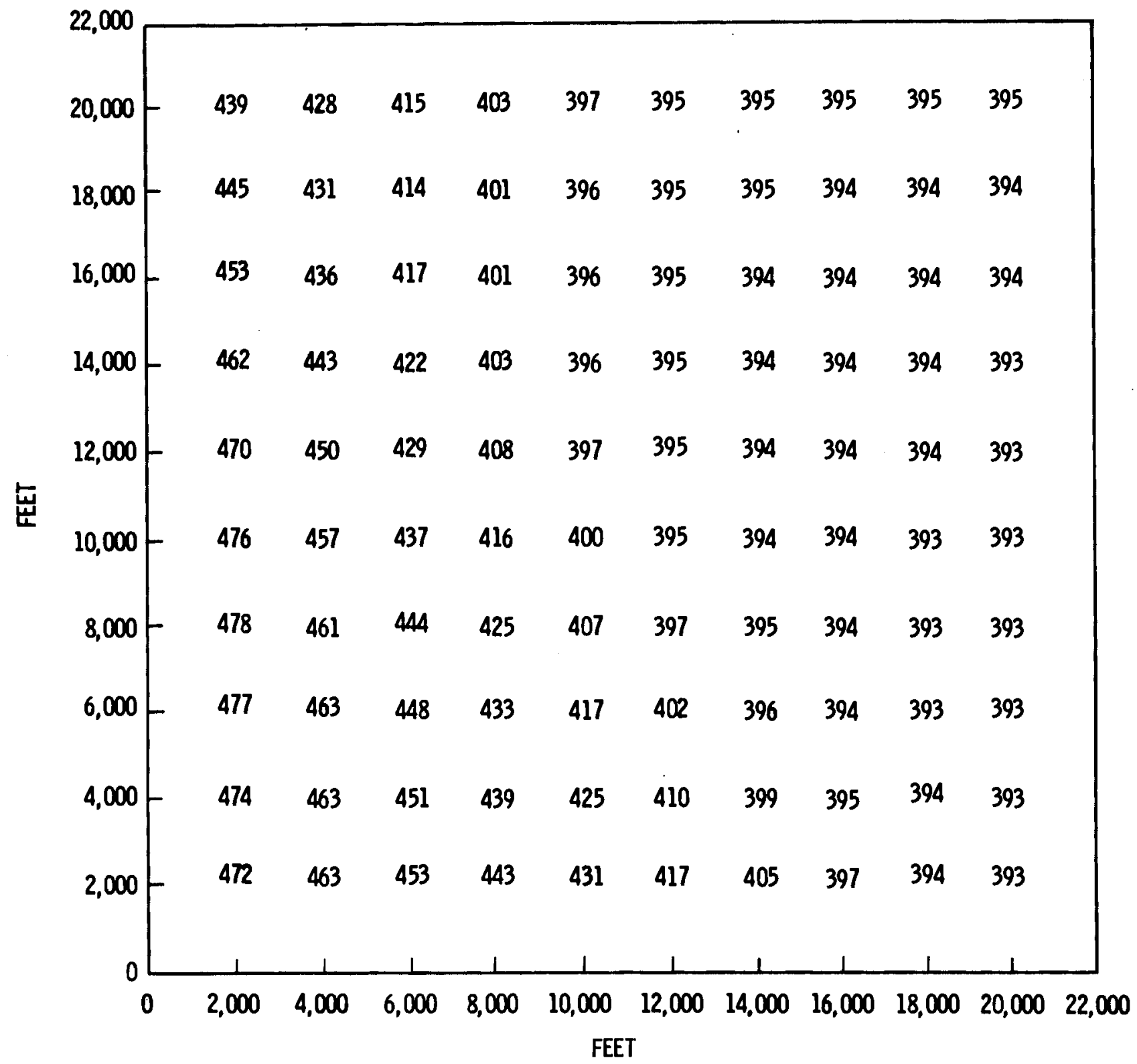

FIGURE 4.5. Potential Data Values

residuals is not surprising, since essentially all spatial correlation between the $\log k$ and $\Phi$ surfaces was removed by subtracting off the estimated values of $E[\log k(x)]$ and $E[\Phi(x)]$.

The covariance function of Equation (4.10) was input to the PNL kriging routine to estimate $\phi(x)$ on the interior $[4000-\mathrm{ft}, 16,000-\mathrm{ft}] \times[4000-\mathrm{ft}$, $16,000-f t]$ region. Figure 4.7 displays the kriged values of $\phi(x)$ on this region. 


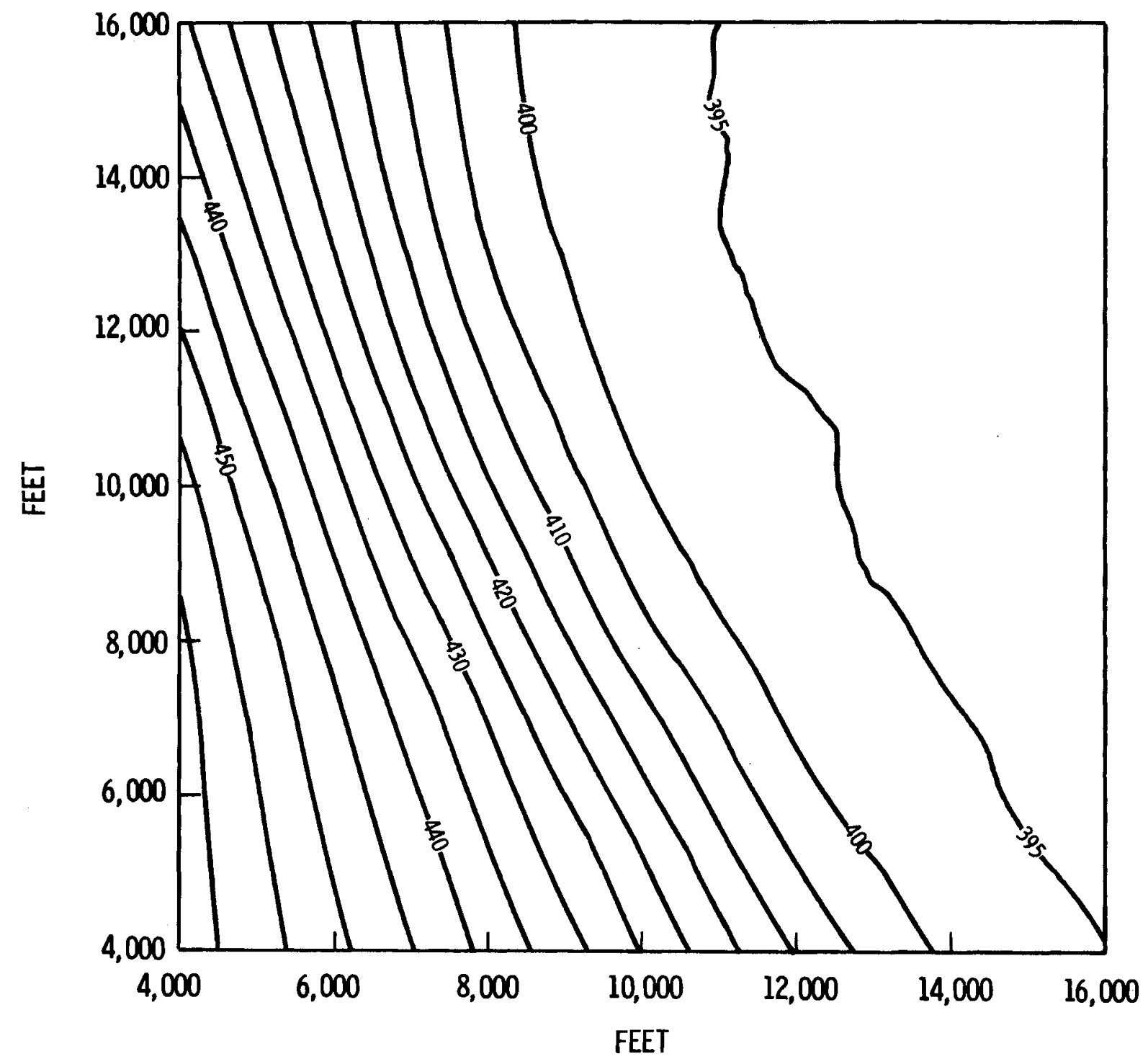

FIGURE 4.7. Contour Plot of $\phi^{\star}(x)(f t)$

where $i=1$ or 2 and $d$ is the distance between $x$ and $y$. Furthermore, it was found that the following two quantities were approximately equal:

$$
\operatorname{Cov}\left(\Phi_{x^{j}}(x),{ }_{x}{ }^{*}{ }_{j}(y)\right)=\operatorname{Cov}\left(\Phi_{x}^{*}{ }_{j}(x),{ }_{x}{ }_{x}{ }^{j}(y)\right)
$$

This permits the following approximation: 


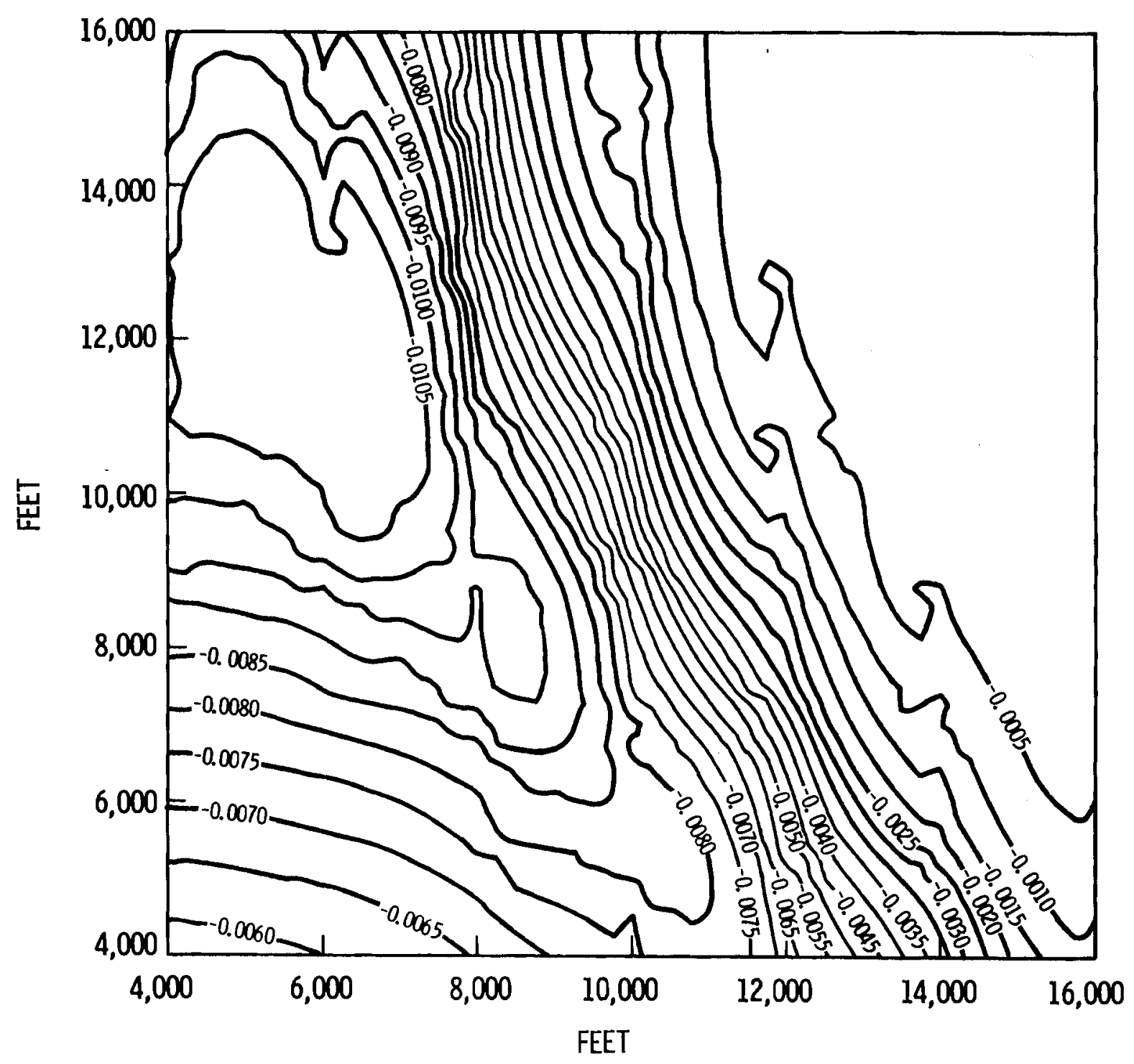

FIGURE 4.8. Contour Plot of $\phi^{*}{ }_{1}$, (east direction gradient)

$$
\begin{aligned}
& \operatorname{Cov}\left(\Phi_{x}{ }_{j}(x), \Phi_{x}{ }_{j}(y)\right)=\operatorname{Cov}\left(\Phi_{x}^{\star}{ }_{j}(x), \Phi_{x}{ }_{j}(y)\right) \\
& -\operatorname{Cov}\left(\Phi_{x^{j}}(x)-\Phi_{x^{*}}(x), \quad \Phi_{i j}(y)-\Phi_{x}^{*}{ }_{j}(y)\right)
\end{aligned}
$$




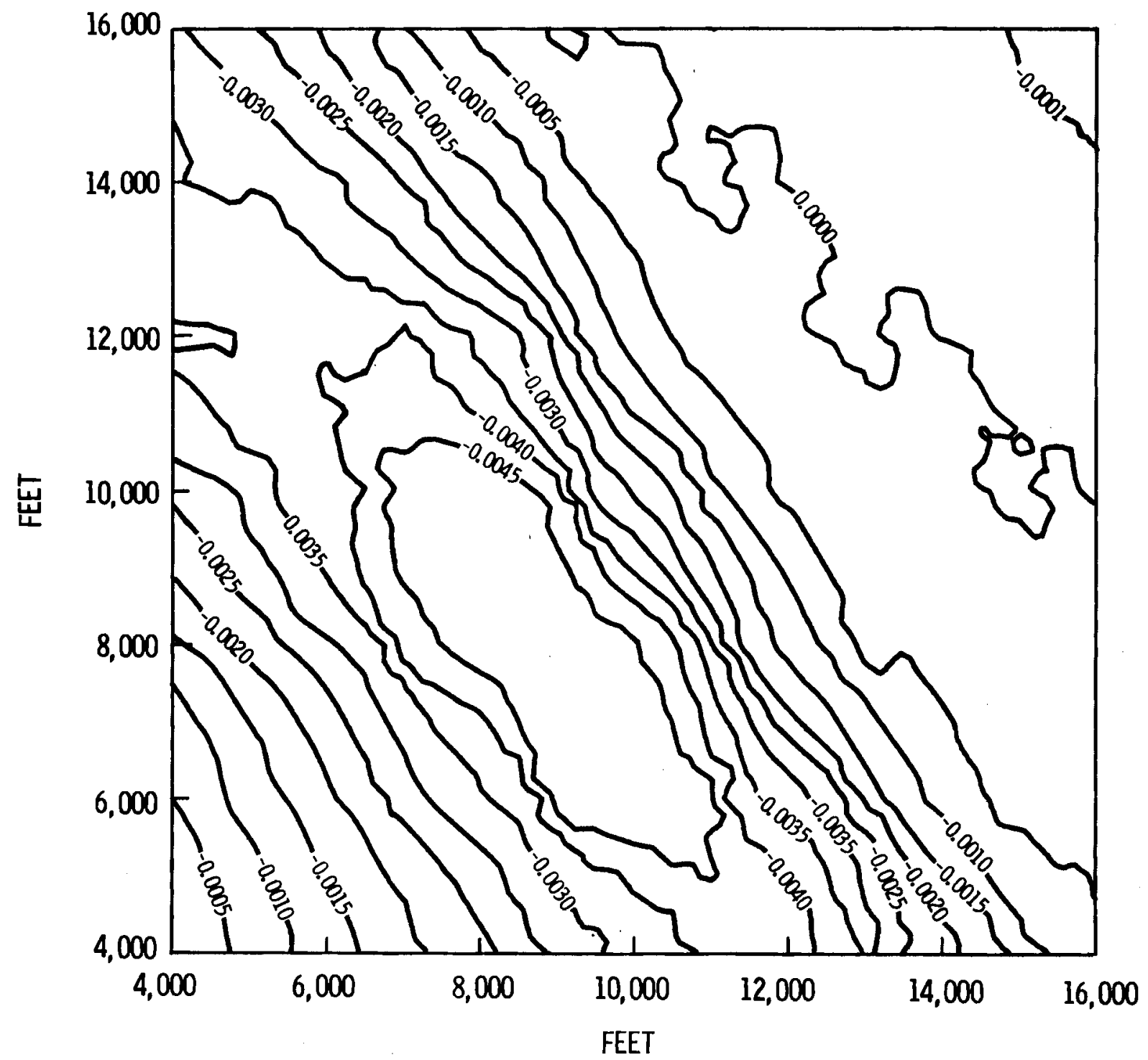

FIGURE 4.9. Contour Plot of $\phi_{x^{2}}(x)$, (north direction $\stackrel{x^{2}}{\text { radient) }}$

\section{PORE VELOCITY CALCULATIONS}

Darcy's law gives the pore velocity as a function of hydraulic conductivity, effective porosity, and ground-water potential:

$$
v(x)=\left(v_{1}(x), v_{1}(x)\right)=-(K(x) / p(x)) \nabla \Phi(x)
$$




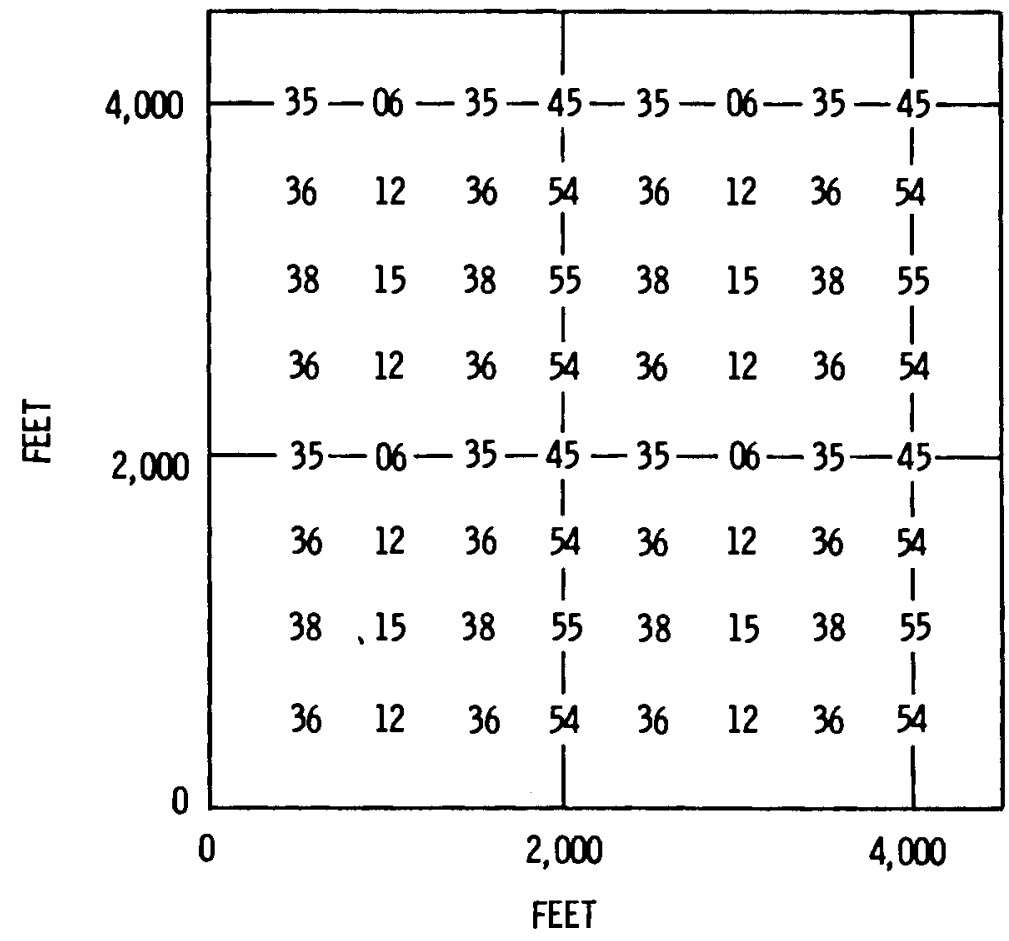

FIGURE 4.10. Kriging Error Standard Deviation Plot for $\phi_{x}^{\star}(x)\left(\right.$ Scale $\left.=\times 10^{-5}\right)$

Since $K(x)$ and $\Phi(x)$ are uncorrelated stochastic processes and $p(x)$ equals the constant value 0.1 , the unbiased estimate of $v(x)$ is given by

$$
V^{\star}(x)=-10 K *(x) \nabla \Phi^{*}(x)
$$

where $k^{\star}(x)$ is given by Equation (4.7) and $\nabla \Phi^{\star}(x)$ is the kriged value of the potential gradient. Figures 4.11 and 4.12 display the pore velocity estimates in the $x^{1}$ (east) and $x^{2}$ (north) directions, respectively, in the [4000-ft, $16,000-\mathrm{ft}] \times[4000-\mathrm{ft}, 16,000-\mathrm{ft}]$ region. Notice that in the region where the conductivity values are largest (upper right quacirant), extremely small potential gradients give rise to significant pore velocities. The complexity of the level curves in this quadrant may be attributed to the high uncertainties (standard deviation equal $3.73 \times 10^{-4}$ ) associated with the kriged estimates of the potential gradient surfaces. 


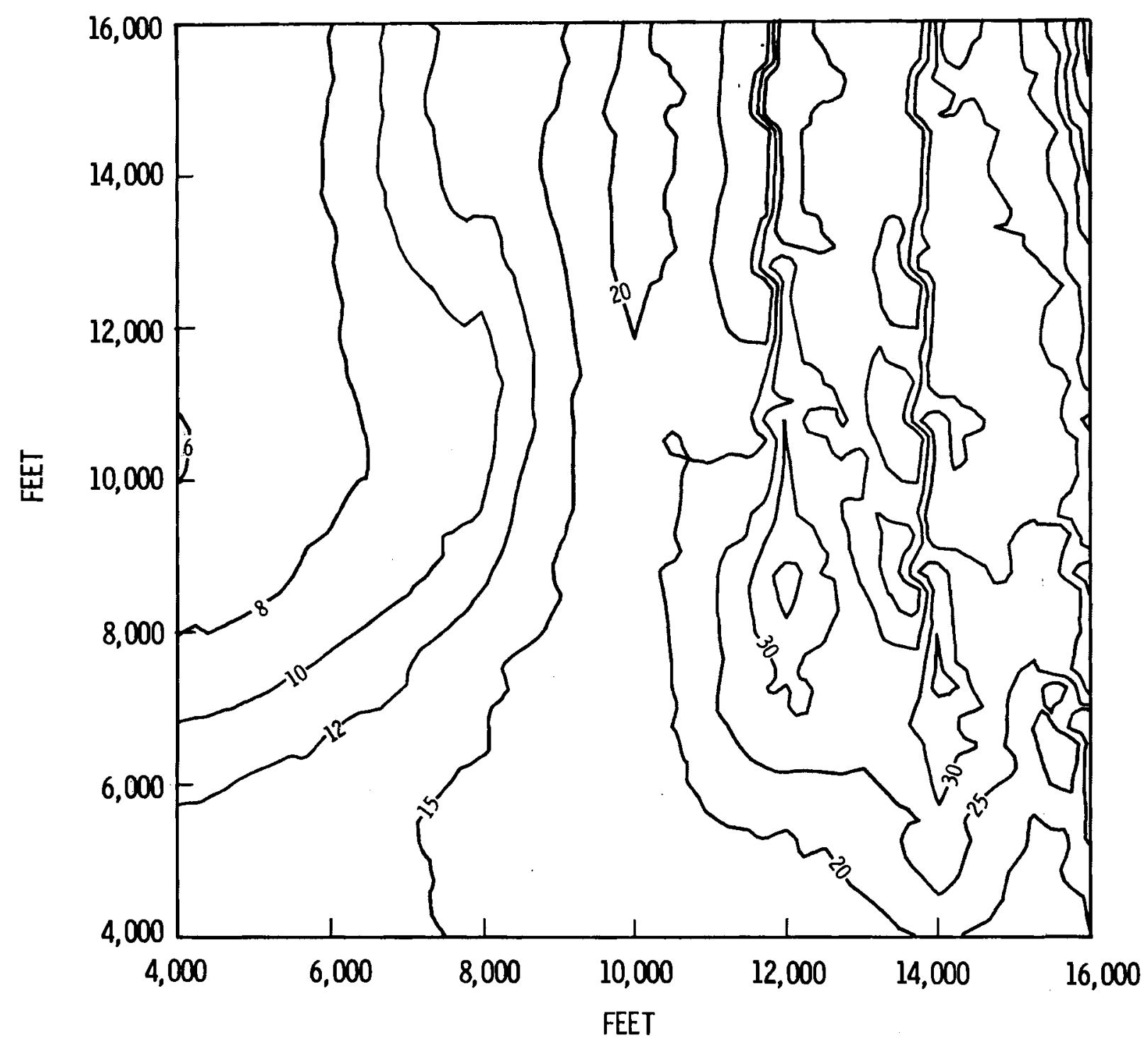

FIGURE 4.11. Contour Plot of $v_{1}^{*}(x)$

(east direction, $f t / d a y$ )

Using Equation (3.7) the variance of the pore velocity estimation error for either coordinate (north or east) is given by:

$$
\begin{gathered}
\operatorname{Var}\left(v_{j}(x)-v_{i}{ }^{*}(x)\right) \\
=100\left(k^{*}(x)\right)^{2}\left(1.784 \times 10^{-7}+3.287 \times 10^{-3}\left(\Phi^{*}{ }_{j}(x)\right)^{2}\right), i=1 \text { or } 2 .
\end{gathered}
$$

Figures 4.13 and 4.14 display the standard deviation of the pore velocity estimation error for the $[4000-\mathrm{ft}, 16,000-\mathrm{ft}] \times[4000-\mathrm{ft}, 16,000-\mathrm{ft}]$ region. 


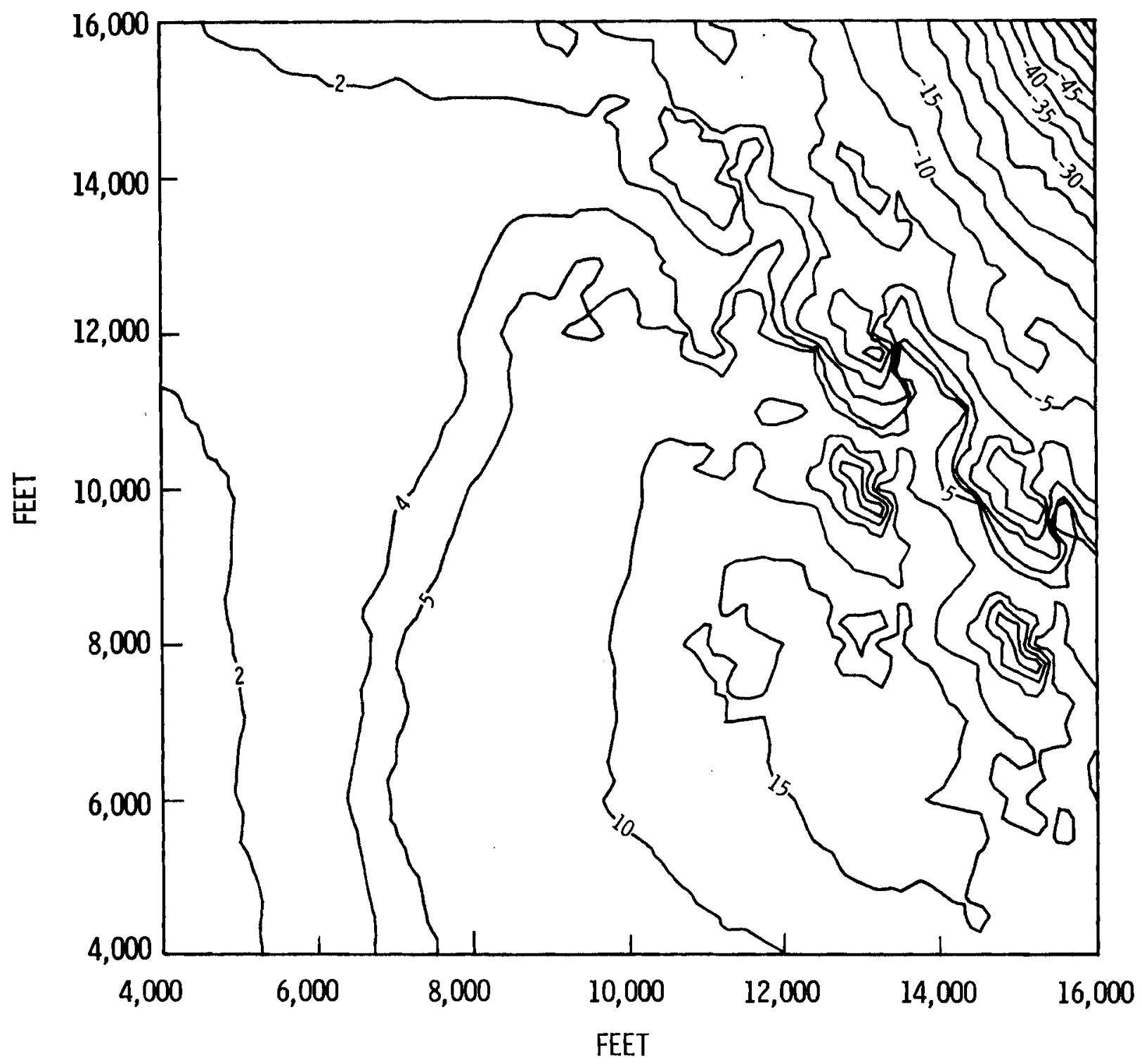

FIGURE 4.12. Contour Plot of $v_{2}{ }^{*}(x)$

(north direction, $\mathrm{ft} /$ day)

As expected the pore velocity estimation uncertainty is largest where the conductivity values increase dramatically and the gradient estimation relative uncertainty is largest (upper right quadrant).

The other covariance terms of the pore velocity estimation error, required for contaminant transport analyses, may be calculated using Equations (3.7) and $(3.8)$. 


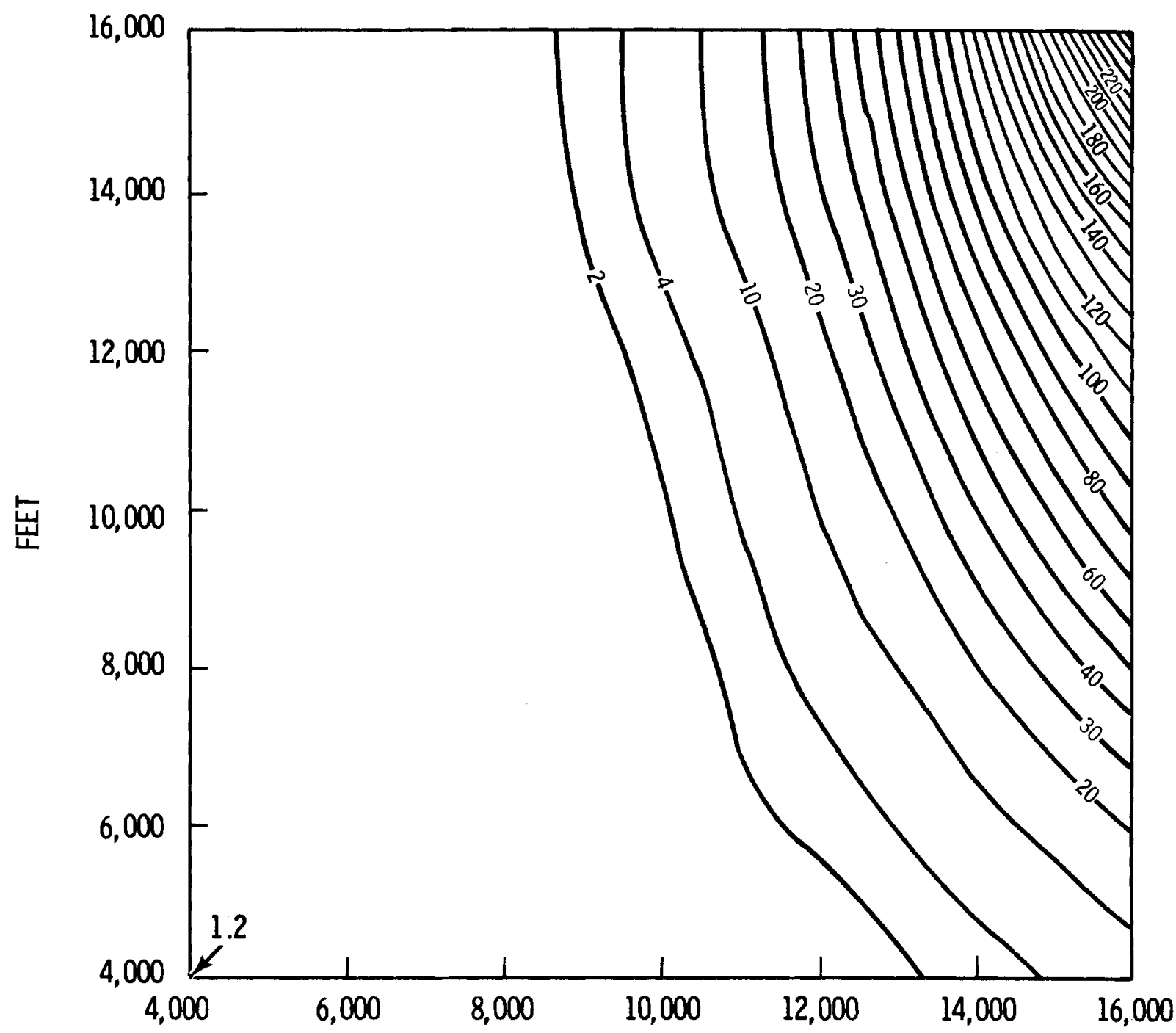

FIGURE 4.13. Contour Plot of the Estimation Error Standard Deviation for $v_{1}{ }^{*}(x)(f t / d a y)$ 


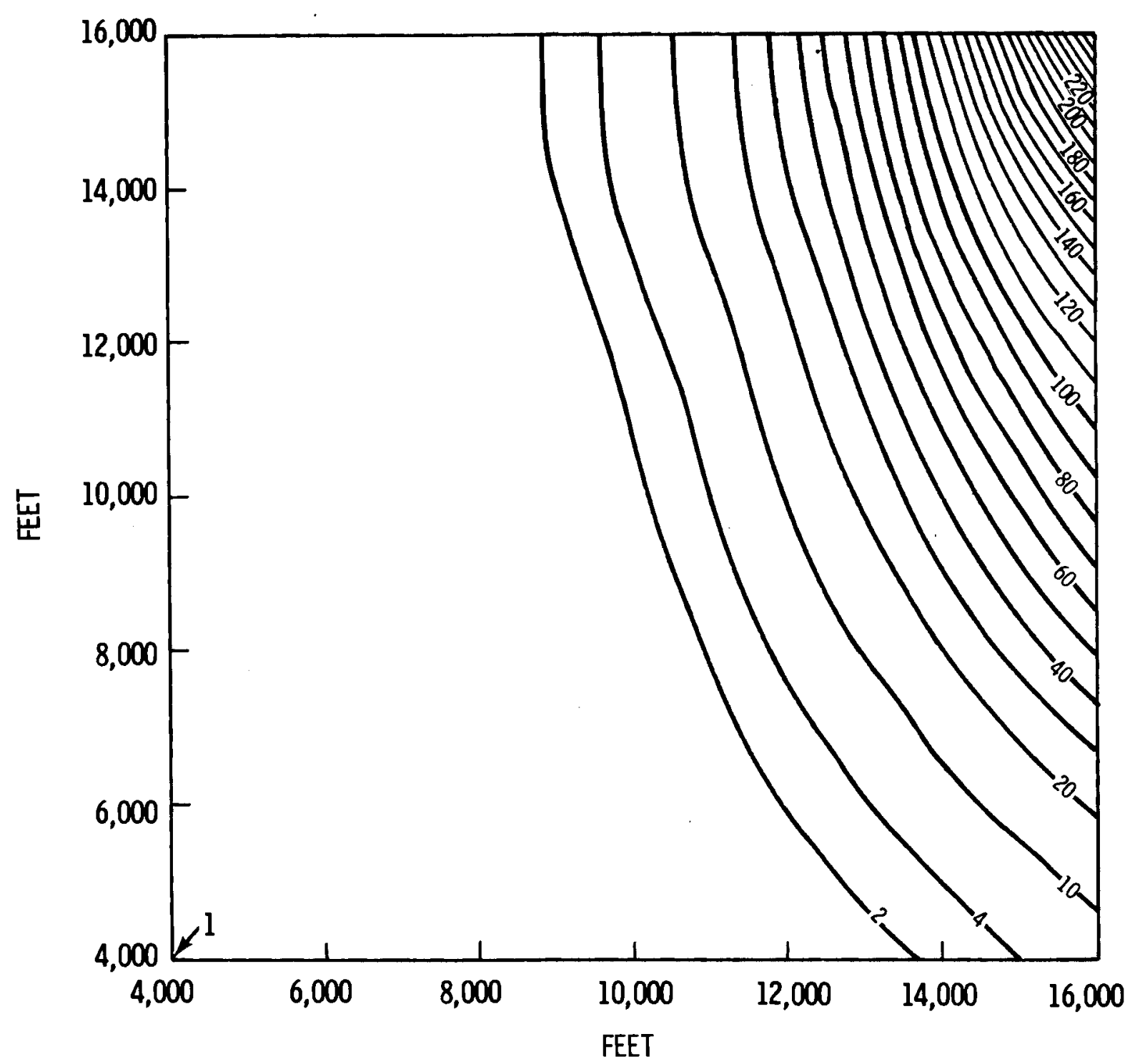

FIGURE 4.14. Contour Plot of the Estimation

Error Standard Deviation for $v_{2}{ }^{\star}(x)$ ( $\mathrm{ft} /$ day) 


\subsection{CONCLUSIONS}

In this paper we have discussed the application of geostatistical data analysis techniques (e.g. kriging) to the modeling of spatially varying hydrologic field parameters. The minimum variance property of kriging algorithms ensures that the maximal amount of information from the expensive well-data is utilized in determining the ground-water flow in a potential repository site. Traditional least squares regression analysis techniques ignore all spatial correlation and continuity present in the field data and add unnecessary uncertainties to the design process.

Kriging estimation techniques were applied to Hanford reservation data to accurately calculate hydraulic conductivities, ground-water potential gradients, and pore velocities. A first order expansion was used to statistically combine hydraulic conductivity and ground-water potential gradient uncertainties (and porosity uncertainties if data exists) to characterize the pore velocity uncertainty. This technique permits the estimation of pore velocity uncertainties even when direct pore velocity measurements do not exist. The product error propogation technique worked well except in the hydrologic region where the ground-water potential gradient was not accurately estimated $(\nabla \Phi \simeq 0.0)$. 


\section{REFERENCES}

Agterberg, F. P. 1974. Geomathematics. Elsevier Scientific Publishing Company, New York, NY.

Akima, H. 1975. "Comments on 'Optimal Contour Mapping Using Universal Kriging' by Ricardo A. 0lea." Journal of Geophysical Research. $80(5): 832-836$.

Bakr, A. A., L. W. Gelhar, A. L. Gutjahr and J. R. MacMillan. 1978. "Stochastic Analysis of Spatial Variability in Subsurface Flows 1. Comparison of One- and Three-Dimensional Flows." Water Resources Research. $14(2): 263-271$.

Bear, J. 1972. Dynamics of Fluids in Porous Media, Elsevier Scientific Publishing Company, New York.

Chiles, J. P. 1975. "How to Adapt Kriging to Non-Classical Problems: Three Case Studies." Advanced Geostatistics in the Mining Industry.

Davis, J. D. 1973. Statistics and Data Analysis in Geology. John Wiley and Sons, Inc., New York.

Delfiner, P. 1975. "Linear Estimation of Non-Stationary Spatial Phenomena." Advanced Geostatistics in the Mining Industry. Eds. M. Guarasco, M. David and C. Huibregts, D. Reidel PubTishing Company, Boston, Massachusetts.

Delfiner, P. 1978. The Intrinsic Model of Order k. Center for Geostatistics. Report C-71. Paris School of Mines, Fontainbleau, France.

Delfiner, P., and J. P. Delhomme. 1975. "Optimum Interpolation by Kriging." Display and Analysis of Spatial Data. Eds. J. C. Davis, and M. J. ilccullagh, John Wiley and Sons, Inc., Hew York.

Delfiner, P. et al. 1979. BLUEPACK 3-D, Center of Geostatistics and Mathematical Hethods, Fontainbleu, France.

Delhomme, J. P. 1978. "Kriging in the Hydrosciences." Advances in Water Resources. 1(5):251-266.

Delhomme, J. P. 1979. "Spatial Variability and Uncertainty in Groundwater Flow Parameters: A Geostatistical Approach." Water Resources Research. $15(2): 269-280$.

Doctor, P. G. 1979. An Evaluation of Kriging Techniques for High Level Radioactive Waste Repository Site Characterization. PNL-2903. Pacific Northwest Laboratory, Richland, Washington. 
Gambolati, G. and V. Giampiero. "Groundwater Contour Mapping in Venice by Stochastic Interpolators 1. Theory." Water Resources Research. 15(2):281-290.

Gelhar, L. W., A. L. Gutjahr and R. L. Naff. 1979. "Stochastic Analys is of Macro-Dispersion in a Stratified Aquifer." Water Resources Research. $15(6): 1387-1397$.

Giampiero, V. and G. Gambolati. 1979. "Groundwater Contour Mapping in Venice by Stochastic Interpolators 2. Results." Water Resources Research. $15(2): 291-297$.

Gutjahr, A. L., L. W. Gelhar, A. A. Bahr and J. R. MacMillan. 1978. "Stochastic Analys is of Spatial Variability in Subsurface Flows 2. Evaluation and Application." Water Resources Research. 14(5):953-959.

Huijbregts, C. J. 1975. "Regionalized Variables and Quantitative Analys is of Spatial Data." Display and Analys is of Spatial Data. Eds. J. C. Davis, and M. J. McCullagh. John Wiley and Sons, Inc., New York.

Krige, D. K. 1966. "Two-Dimensional Weighted Moving Average Trend Surfaces for Ore Valuation." Journal of the South African Institute of Mining and Metallurgy. pp. 13-79.

Lillie, J. J. and B. H. Richard. 1977. An Analysis of Selected Gravity Profiles on the Hanford Reservation Richland, Washington. Rockwel1Hanford Operations, Richland, WA 99352. Report RHO-BWI-C-6.

Natheron, G. 1963. "Principles of Geostatistics." Economic Geology. $58: 1246-1266$.

Matheron, G. 1971. The Theory of Regionalized Variables and its Applications. Vol. 5. Centre for Mathematical Morphology, Paris School of Mines, Fontainebleau, France.

01ea, R. A. 1974. "Optimal Contour Mapping Using Universal Kriging." Journal of Geophysical Research. 79(5):695-702.

Parzen, E. 1962. Stochastic Processes, Holden Day Inc, , San Francisco, Cal ifornia.

Watson, G. S. 1972. "Trend Surface Analysis and Spatial Correlation." Geological Society of America Special Paper 146. 


\section{DISTRIBUTION}

No. of

Copies

OFFSITE

\section{UNITED STATES}

\section{A. A. Churm}

DOE Chicago Patent Group

9800 South Cass Avenue

Argonne, IL 60439

27 DOE Technical Information Center

2 Argonne National Laboratory Technical Information Services

Report Section

Building 2 of 3, CEl25

9700 South Cass Avenue

Argonne, IL 60439

10 Battelle Memorial Institute

Office of Nuclear Waste Isolation

Attn: Beverly Rawles

505 King Avenue

Columbus, $\mathrm{OH} 43201$

Michael J. Be11, Chief

High-Level Waste Technical Development Branch

Waste Management Division

U.S. Nuclear Regulatory Commission Washington, DC 20555

John Bird

Geology Department

Corne11 University

Ithaca, NY 14853

Albin Brandstetter

Office of Nuclear Waste Isolation

Battelle Memorial Institute

505 King Avenue

Columbus, $\mathrm{OH} 43201$
No. of

Copies

2 Brookhaven National Laboratory

Reference Section

Information Division

Upton, Long Is land, NY 11973

Harry C. Burkholder

Office of Nuclear Waste Isolation

Battelle Memorial Institute

505 K.ing̃ Avenue

Columbus, $\mathrm{OH} 43201$

Neville G. W. Cook

Dept. of Materials Science and Mineral Engineering

Hearst Mining Building

University of California

Berkeley, CA 94720

Carl R. Cooley

DOE Office of Nuclear Waste Management

Washington, DC 20545

Mike Cullingford

Probablistic Analys is Staff

Nuclear Regulatory Commission

Mail Stop 3103

Washington, DC 20555

Stanley N. Davis, Hydrologist

The University of Arizona

College of Earth Sciences

6540 W. Box Canyon Drive

Tucson, AZ 85705

James 0. Duguid

Battelle Memorial Institute

Office of Nuclear Waste Isolation

505 King Avenue

Columbus, $\mathrm{OH} 43201$ 
No. of

Copies

Dan Egan

Environmental Protection Agency

Office of Radiation Programs

Technology Assessment Division

M/S AW559

Washington, DC 20460

Warren Eister

Department of Energy

Division of Waste Isolation

Washington, DC 20545

Bruce R. Erdal

Los Alamos Scientific Laboratory

CNC- 11 , MS -514

Los Alamos, NM 87545

Larry R. Fitch

Office of Licensing

Systems Integration

Basalt Waste Isolation Project

Rockwell Hanford Operations

P. 0. Box 800

Richland, WA 99352

Robert M. Garrells

Dept. of Geologic Sciences

Northwestern University

Evanston, IL 60201

Mark A. Harwell

P.0. Box 667

Cannon Beach, OR 97110

Colin A. Heath

DOE Office of Nuclear Waste

Management

Washington, DC 20545

William M. Hewitt

Office of Nuclear Waste Isolation

Battelle Memorial Institute

$505 \mathrm{King}$ Avenue

Columbus, $\mathrm{OH} 43201$
No. of

Copies

Peter L. Hofmann

Office of Nuclear Waste Isolation

Battelle Memorial Institute

505 King Avenue

Columbus, $\mathrm{OH} 43201$

Muzaffer Kehnemuyi

Office of Nuclear Waste Isolation

Battelle Memorial Institute

505 King Avenue

Columbus, $\mathrm{OH} 43201$

John F. Kircher

Office of Nuclear Waste Isolation

Battelle Memorial Institute

505 King Avenue

Columbus, $\mathrm{OH} 43201$

C. Kreitler

Texas Bureau of Economic Geology

University Station

P.0. Box X

Austin, TX 78712

Terry R. Lash

Director of Science and Public Policy

Keystone Center

Box 38

Keystone, CO 80435

2 Lawrence Berkeley Laboratory

Reference Library

University of California

Berkeley, CA 94720

2 Lawrence Livermore Laboratory

Reference Library

P.0. Box 808

Livermore, CA 94550

Stan E. Logan

Los Alamos Technical Assoc.

P.0. Box 410

Los Alamos, NM 87544 
No. of

Copies

Tom Longo

Department of Energy

Division of Waste Isolation

Washington, DC 87544

2 Los Alamos Scientific Laboratory

Reference Library

P. 0. Box 1663

Los Alamos, NM 87544

J. B. Martin

Asst. Director for Radioactive Waste Management Branch

NRC Division of Materials and

Fuel Cycle Facility Licensing

Washington, DC 20555

John T. McGinnis

Office of Nuclear Waste Isolation

Battelle Memorial Institute

505 King Avenue

Columbus, $\mathrm{OH} 43201$

M. Merritt

WIPP, Division 4512

Sandia Laboratories

Albuquerque, NM 87115

Martin A. Molecke

Nuclear Waste Experimental Programs

Division 4512

Sandia Laboratories

Albuquerque, NM 87185

2 Barry N. Naft

NUS Corporation

4 Research Place

Rockville, MD 20805

2 Jeff 0 . Neff

Department of Energy

Columbus Program Office

505 King Avenue

Columbus, $\mathrm{OH} 43201$
No. of

Copies

2 Neil A. Norman

Environmental Sciences Department

Bechtel National Inc.

P.0. Box 3965

San Francisco, CA 94105

2 Oak Ridge National Laboratory

Central Research Library

Document Reference Section

Oak Ridge, TN 37830

Frank L. Parker

Dept. of Environmental Engineering

Vanderbilt University

Nashville, TN 37235

T. H. Pigford

University of California

Berkeley, CA 94720

George F. Pinder

Dept. of Civil Engineering

Princeton University

Princeton, NY 08540

Robert 0 . Poh 1

Laboratory of Atomic and

Solid State Physics

Cornell University

Ithaca, NY 14853

H. L. Ragsdale

Department of Biology

Emory University

Atlanta, GA 30322

Gilbert E. Raines

Office of Nuclear Waste Isolation

Battelle Memorial Institute

505 King Avenue

Columbus, $\mathrm{OH} 43201$

Herbert R. Shaw

U.S. Department of the Interior

Geological Survey

Branch of Experimental Geochem. and Mineralogy

345 Middlefield Road

Menlow Park, CA 94025 
No. of

Copies

D. B. Shipler

Battelle Memorial Institute

Office of Nuclear Waste Isolation

505 King Avenue

Columbus, $\mathrm{OH} 43201$

2 Savannah River Laboratory

Reference Library

Aiken, SC 29801

Arthur J. Soinski

Energy Resources Conservation and Development Commission

1111 Howe Avenue

Sacramento, CA 95825

Howard P. Stephens

Sandia Laboratories

P.0. Box 5800

Albuquerque, NM 87115

David B. Stewart

U.S. Geological Survey

National Center 959

Reston, VA. 22092

Martin S. Tierney

Environmental Assessment

Division 4514

Sandia Laboratories

Albuquerque, NM 87115

Newell J. Trask, Geologist

U.S. Department of the Interior

Geological Survey

Reston, VA 22092

Bob E. Watt

1447 45th Street

Los Alamos, NM 87544

R. E. Wilems

INTERA Environmental

Consultants, Inc.

11999 Katy Freeway, Suite 610

Houston, TX 77079
No. of

Copies

Robert Williams

Electric Power Research Inst.

3412 Hillview Avenue

P.0. Box 10412

Palo Alto, CA 94304

Paul A. Witherspoon

Earth Sciences Division

Lawrence Berkeley Laboratory

Building 90

Berkeley, CA 94720

\section{ONSITE}

5 DOE Richland Operations Office

0. J. Elgert

R. B. Goranson

H. E. Ransom

J. J. Schreiber

F. R. Standerfer

12 Rockwell Hanford Operations

R. C. Arnett

R. G. Baca

R. L. Bielefeld

D. J. Carrell

R. A. Deju

F. A. Deluca

L. R. Fitch

R. E. Gephart

L. S. Leonhart

Rockwe11 Document Control

Rockwell Library (2)

86 Pacific Northwest Laboratory

E. M. Arnold

G. L. Benson

D. J. Bradley

T. D. Chikalla

M. O. Cloninger

C. R. Cole

W. J. Deutsch

J. L. Devary (25)

P. G. Doctor 
No. of

Copies

F. H. Dove (20)

M. G. Foley

F. N. Hodges

C. T. Kincaid

M. R. Kreiter

B. K. Marshall

G. L. McVay

R. W. Nelson

R. D. Peters

G. M. Petrie

A. M. Platt

J. V. Robinson

R. J. Serne

J. W. Shade

D. J. Silveria

J. K. Soldat

J. T. Zellmer

Technical Information Library (5)

Publishing Coordination (2)

Water and Land Resources Dept. Library (10) 
